NBER WORKING PAPER SERIES

\title{
FORWARD GUIDANCE
}

Lars E.O. Svensson

Working Paper 20796

http://www.nber.org/papers/w20796

\author{
NATIONAL BUREAU OF ECONOMIC RESEARCH \\ 1050 Massachusetts Avenue \\ Cambridge, MA 02138 \\ December 2014
}

A previous version of the paper, without the U.S. experience, was presented at the RBNZ and IJCB conference "Reflections on 25 Years of Inflation Targeting," held in Wellington, New Zealand, December 1-2, 2014. I thank Ozer Karagedikli and Edward Nelson for comments, Christopher Sims for comments on and discussion of a previous version of this paper, and Martin Edmonds, David Gillmore, Ava Hong, and Bingjie Hu for research assistance. The views expressed and any errors are my own responsibility. The views expressed herein are those of the author and do not necessarily reflect the views of the National Bureau of Economic Research.

NBER working papers are circulated for discussion and comment purposes. They have not been peerreviewed or been subject to the review by the NBER Board of Directors that accompanies official NBER publications.

(C) 2014 by Lars E.O. Svensson. All rights reserved. Short sections of text, not to exceed two paragraphs, may be quoted without explicit permission provided that full credit, including $(\mathrm{C}$ notice, is given to the source. 
Forward Guidance

Lars E.O. Svensson

NBER Working Paper No. 20796

December 2014, Revised July 2015

JEL No. E52,E58,G14

\begin{abstract}
$\underline{\text { ABSTRACT }}$
Forward guidance about future policy settings, in the form of a published policy-rate path, has for many years been a natural part of normal monetary policy for several central banks, including the Reserve Bank of New Zealand and the Swedish Riksbank. More recently, the Federal Reserve has started to publish FOMC participants' policy-rate projections. The Swedish, New Zealand, and U.S. experience of a published policy-rate path is examined, especially to what extent the market has anticipated the path (the predictability of the path) and to what extent market expectations line up with the path after publication (the credibility of the path). The recent Swedish experience is quite dramatic. In particular, it shows a case with a large discrepancy between a high and rising Riksbank path and a low and falling market path, with the market path providing a good forecast of the future policy rate. The discrepancy is explained by the Riksbank's leaning against the wind in recent years and related circumstances. The New Zealand experience is less dramatic, but shows cases where the market implements either a substantially tighter or easier policy than intended by the RBNZ. There are also cases of the market being ahead of the RBNZ and the RBNZ later following the market. The U.S. experience includes a recent case of the market expecting and implementing substantially easier policy consistent with the FOMC projections, the possible explanation of which has been much discussed.
\end{abstract}

Lars E.O. Svensson

Department of Economics

Stockholm School of Economics

P.O. Box 6501

SE-11383 Stockholm

Sweden

and Stockholm University

and also NBER

lars.svensson@iies.su.se 


\section{Introduction}

"Forward guidance" in monetary policy means providing some information about future policy settings. In recent years, the Federal Reserve, the Bank of Canada, the ECB, and the Bank of England have used different forms of forward guidance. The forward guidance by these central banks was introduced in the special context of a binding lower bound for the policy rate. It has been used as a way of implementing more expansionary policy when the policy rate has been restricted by a lower bound.

In contrast, for many years, some central banks have used forward guidance as a natural part of their normal monetary policy. This forward guidance has been in the specific form of a published forecast for the interest rate, either the policy rate or a 90-day interest rates. The Reserve Bank of New Zealand has published a path for the 90-day rate from 1997, Norges Bank for the policy rate from 2005, Sveriges Riksbank and Bank of Israel for the policy rate from 2007, and the Czech National Bank for a 90-day rate from 2008. More recently, the Federal Reserve has published a forecast for its policy rate from 2012, in the form of the "dot plot" collecting individual FOMC participant's judgment of the appropriate level of the policy rate over three calendar years and the longer run.

In this paper, I look more closely at the Swedish, New Zealand, and U.S. experience of publishing an interest-rate path. Especially, by comparing the published interest-rate path with market expectations of future interest rates before and after the publication, one may assess both the predictability of monetary policy, that is, how well the market anticipated the new interest-rate path, and the credibility of the published interest-rate path, that is, to what extent the market expectations line up with the interest-rate path after publication. Furthermore, if after the publication market expectations line up well with the published interest-rate path, this indicates that the actual financial conditions, given by the actual market yield curve, are equal to the intended financial conditions, the yield curve consistent with the published interest-rate path. Then, monetary policy is successful in managing expectations (Woodford 2005).

Regarding the predictability and credibility of the interest-rate path, the Swedish experience includes examples of both great successes and great failures. In particular, the paper examines the circumstances of the great failure of September 2011, when the Riksbank announced a high and increasing policy-rate path. It indicated a rise in the policy rate by about 75 basis points over the next six quarters. However, before and after the announcement, market expectations indicated a fall of about 75 basis points over the next six quarters. This was hence a situation when the published interest-rate path completely lacked credibility, and the actual financial conditions were substantially easier than the intended ones. Ex post, the market expectations were right and the Riksbank interest-rate path was wrong. The Riksbank actually lowered the policy rate by 100 basis points over the next six quarters. This failure is better understood, once the complex broader picture of Swedish monetary policy at the time is explained. The Riksbank actually conducted a very controversial and aggressive leaning against the wind. ${ }^{1}$ Furthermore, although this was a failure in view of the intended monetary policy, it was arguably not a failure in view of the rather weak economy, which arguably very much needed the easy conditions delivered by the market.

Regarding the predictability and credibility of the interest-rate path, the New Zealand experience of successes and failures is much less dramatic. This is not strange given that New Zealand's monetary

\footnotetext{
${ }^{1}$ During my period as Deputy Governor and Executive Board member of the Riksbank, I consistently dissented against this policy.
} 
policy appears to have been better focused on achieving its objectives. ${ }^{2}$ There are no failures of predictability and credibility of the magnitude seen in Sweden. Still, I find a case when the actual financial conditions are clearly tighter than the intended ones, and another when the actual financial conditions are substantially easier than intended. In the latter case, the market seems to have been ahead of the RBNZ, because the next published interest-rate path was shifted down substantially, making the new intended financial conditions much easier and more or less in line with those previously anticipated by the market.

The U.S. experience of a published policy-rate path is short, because it only started in January 2012. Furthermore, one must keep in mind that the "path" is not the outcome of a joint committee decision. In this paper, as in most discussions of the FOMC's dot plot, the policy-rate path is constructed as the median of the FOMC participants' individual assessments for each specified year. But because the voters of the FOMC are a rotating subset of the participants, the policy-rate path constructed this way is not necessarily the median of the voting participants' assessment. Even if the median of the voters' assessments were known, it would not necessarily be the case that a joint committee decision would correspond to that median. This would depend on the dynamics of the decision process of the FOMC; for instance, the Chair's assessment is likely to carry more weight. These qualifications must be kept in mind, when the median policy-rate path is used as an approximation to a joint FOMC decision. That said, during 2012 and 2013, market expectations have been either a bit below or well aligned with the FOMC policyrate path. For instance, the December 2013 policy-rate path was very well anticipated by the market and highly credible after publication. During 2014, however, market expectations of future policy rates have fallen increasingly below FOMC participants' policy-rate paths, the possible reasons for which have been much discussed and are further commented on below. Thus far during the short U.S experience, there is no case where the actual financial conditions implemented by the market have been tighter than what is consistent with the FOMC participant's policy-rate path.

Section 2 discusses forward guidance as a special or normal part of monetary policy and possible reasons why publication of an interest-rate path would be a normal part of monetary policy. Section 3 discusses the practical experience of forward guidance in Sweden, in particular the large discrepancy between the Riksbank's policy-rate path and market expectations of future policy rates in September 2011. Section 4 discusses some specific aspects of the discrepancy of September 2011, whereas section 5 discusses some broader aspects of the Riksbank policy at the time. Section 6 discusses the much less dramatic New Zealand experience, against the background of the broader picture of monetary policy in New Zealand, very different from that in Sweden. Section 7 discusses the short U.S. experience. Section 8 concludes.

\section{Forward guidance as a special or normal policy}

\footnotetext{
${ }^{2}$ However, the RBNZ arguably made a mistake in relying too much on a monetary-conditions index (MCI) in the late 1990s. At the invitation of New Zealand's Minister of Finance, I conducted a review of the operation of monetary policy in New Zealand during the first 10 years of inflation targeting (Svensson 2001). My overall conclusions was that "with regard to the operational framework and how monetary policy is managed in pursuit of the inflation target, I have found that the period (mid 1997 to March 1999) when the Reserve Bank used a Monetary Conditions Index (MCI) to implement monetary policy represents a significant deviation from best international practice. This has now been remedied, and monetary policy in New Zealand is currently entirely consistent with the best international practice of flexible inflation targeting, with a medium-term inflation target that avoids unnecessary variability in output, interest rates and the exchange rate. Only some marginal improvements, mostly of a technical nature, are recommended."
} 
In recent years, the Federal Reserve, the Bank of Canada, the ECB, and the Bank of England have used different forms of verbal forward guidance - meaning some information in policy statements about future monetary-policy settings in order to affect market expectations about future policy settings. The forward guidance by these central banks was introduced in the context of a binding lower bound for the policy rate. It has been used as a way of implementing a more expansionary policy when the policy rate has been restricted by a lower bound.

Forward guidance in the specific form of a published forecast for the interest rate has been used by the Reserve Bank of New Zealand from 1997, by Norges Bank from 2005, the Riksbank from 2007, the Bank of Israel from 2007, and the Czech National Bank from 2008. That kind of forward guidance is a normal part of the policy and communication of these central banks. These central banks all pursue flexible inflation targeting, meaning that the objective of the policy is to stabilize both inflation targeting around an announced inflation target and resource utilization around its long-run sustainable rate. ${ }^{3}$ More recently, in January 2012, the Federal Reserve, with its "Statement on Longer-Run Goals and Monetary Policy Strategy" (Federal Open Market Committee 2012a), became a very transparent flexible inflation targeter. It also started to publish a forecast for its policy rate, in the specific form of a scatter plot where each dot indicates the value of an individual FOMC participant's judgment of the appropriate level of the target federal funds rate at the end of three calendar years and over the longer run.

Which measure of resource utilization is most appropriate may vary from economy to economy. For concreteness, I here use the unemployment rate as the relevant measure of resource utilization. At least in Sweden the unemployment rate and the gap to an estimated long-run sustainable rate are in my view a much more reliable indicator of resource utilization than the output gap, which relies on very shaky, arbitrary and unverifiable estimates of potential output (Svensson 2011). In New Zealand, the RBNZ uses the output gap as the main measure of resource utilization. The Federal Reserve's mandate of promoting price stability and maximum employment makes it natural that it as measures of resource utilization focuses on the gap between employment and its assessment of the maximum level of employment and the gap between unemployment and the "longer-run normal rate of unemployment" (Federal Open Market Committee 2012a).

There are several reasons why forward guidance in the form of a published forecast for interest rate (a policy-rate path or a path for a market 90-day rate consistent with the central-bank policy-rate path) may be considered a natural part of a monetary policy in the form of flexible inflation targeting:

(1) Transparency. Because the economy reacts with a lag to monetary-policy actions, monetary policy has to be guided by central-bank forecasts for inflation and unemployment. A coherent forecast for inflation and unemployment requires a forecast for the policy rate. Coherent flexible inflation targeting requires "forecast targeting," that is, choosing a policy-rate path such that the corresponding forecasts for inflation and unemployment "look good," meaning that they best stabilize both inflation around the target and unemployment around its long-run sustainable rate. Because the policy-rate path is inherent in forecast targeting, transparency of policy requires the publication of forecasts for both the target variables (inflation and unemployment) and the policy rate.

\footnotetext{
${ }^{3}$ In a public lecture at Victoria University, Wellington, given in the fall of 1997 (Svensson 1998), I argued that there was evidence from 1996-1997 of the RBNZ being a flexible inflation targeter (stabilizing both inflation and resource utilization) rather than a strict inflation targeter (only concerned about stabilizing inflation, regardless of the stability of the real economy).
} 
(2) Effectiveness. A published policy rate should affect market expectations of future policy rates and thereby the yield curve and longer market rates that have an impact on economic agents' decision and this way contribute to a more effective implementation of monetary policy. ${ }^{4}$ (The publishing of forecasts for inflation and unemployment should also affect the expectations of those variables and contribute to a more effective implementation of policy; see Svensson and Woodford 2005).

(3) Informativeness. Generally, the central bank should have better information about its plans for the future policy rate than any other agent. A published policy-rate path should therefore provide useful information for the private sector and the public authorities about future policy rates, which should contribute to more informed decisions.

(4) Justification. Published forecasts for the policy rate, inflation and unemployment allow a transparent and coherent way of justifying the policy choice by comparing the policy choice with the policy alternatives.

(5) Accountability. Published forecasts for the policy rate, inflation, and unemployment simplify an external evaluation of monetary policy and thereby increase the accountability of the central bank. It allows an external assessment of the tradeoff between target variables and the consistency of the policy-rate path with the forecasts for the target variables. If instruments other than the policy rate are also used, such as those of balance-sheet policies, logic and consistency would demand the publication of forecasts for those as well.

In earlier parts of their inflation-targeting years, many inflation targeting central banks assumed a constant policy-rate path when they constructed their inflation forecasts. The idea was that a constant-policy-rate inflation forecast that overshoots (undershoots) the inflation target at some horizon, such as two years, indicates that the policy rate needs to be increased (decreased) (Jansson and Vredin 2003; Vickers 1998). However, those central banks gradually became aware of a number of problems with the assumption of constant interest rates (Leitemo 2003; Woodford 2005). The assumption may often be unrealistic and therefore imply biased forecasts, and it may imply either explosive or indeterminate behavior in standard models of the transmission mechanism of monetary policy. In particular, even if a constant-interest-rate inflation forecast is on target at an appropriate horizon, it will typically overshoot or undershoot the target shortly after that horizon, meaning that the policy-rate will have to be adjusted soon, thus violating the assumption of a constant future policy rate. This would make rational market expectations deviate from the constant policy rate. Furthermore, the forecasting process will use inputs such as asset prices that are conditional on market expectations of future interest rates rather than a constant interest rate and will therefore produce inconsistent and difficult-to-interpret forecasts.

Some inflation-targeting central banks then moved to a policy-rate assumption equal to the market expectations of future interest rates, as they can be extracted from explicit forward rates and implied forward rates from the yield curve. This reduces the number of problems mentioned above but did not eliminate them fully. For instance, the central bank may have a view of the appropriate future policy-rate path that differs from that of the market.

The move to publishing the central bank's own policy-rate path solves all the above problems only if the policy-rate path is credible, that is, if market expectations adjust to the policy-rate path when it is

\footnotetext{
${ }^{4}$ If the central bank's implementation of its monetary policy allows a substantial difference between the central bank's policy rate and the market overnight rate, as has often been the case for the euro area, the relevant interestrate forecast is really the forecast for the overnight rate.
} 
published. If not, this means that some inputs in the forecasting process, such as the exchange rate and other asset prices, are still not consistent with the published policy-rate path, making the forecasts for inflation and unemployment inherently inconsistent. As we shall see, this particular problem has been an issue in Sweden in the last few years. ${ }^{5}$

\section{The recent Swedish experience of forward guidance}

Figure 1 shows the Riksbank's policy rate (the repo rate) and the new policy-rate path announced at each meeting, starting in February 2007 when the first policy-rate path was published and ending with the new policy-rate path in July 2014, when the policy rate was lowered from 0.75 percent to 0.25 percent. In October 2014, the policy rate was lowered to 0 percent. The new policy-rate path (not shown) was shifted down to zero, with the first rise in the beginning of 2016. In February 2015, the policy rate was lowered to minus 0.1 percent, and in an extra policy meeting in March 2015, it was lowered to minus 0.25 percent, with a statement that it was expected remain at that level at least until the second half of 2016 (not shown).

[Figure 1]

The recent Swedish experience during and after the financial crisis 2008-2009 provides an interesting case study of forward guidance in the form of a published policy-rate path. By comparing the published policyrate path with market expectations of the future policy rate - which I will call the market policy-rate paths - before and after the publication, one may assess both the predictability of monetary policy and the credibility of the policy-rate path. ${ }^{6}$

(1) Predictability. Ideally, monetary policy should be so predictable that markets anticipate the new central-bank policy-rate path well. This should show up as the market policy-rate path the day before the publication of the new central-bank policy-rate path being close to the published policy-rate path.

(2) Credibility. Furthermore, after the publication of the central-bank policy-rate path, its credibility with the market should ideally be so high that the market policy-rate path shifts in the direction of the path and lines up well with it.

Note that "credibility" here refers only to the extent to which market expectations are in line with the published interest-rate path, regardless of whether the interest-rate path is appropriate in achieving the monetary-policy objectives.

Figure 2 shows the Riksbank policy rate and the market policy-rate paths after the announcement of the new policy-rate and policy-rate path.

[Figure 2]

\footnotetext{
${ }^{5}$ Gosselin, Lotz and Wyplosz (2008) provide a theoretical analysis of transparency and opaqueness of the central bank's policy-rate path. The pros and cons of publishing a policy-rate path are discussed in further detail in Svensson $(2006,2009)$ and Woodford $(2005,2007)$.

${ }^{6}$ Market expectations of future policy rates are constructed at the Riksbank as implied forward-rate curves. They are adjusted by the Riksbank staff for liquidity, credit, and term premia, so as to be the staff's best estimate of market expectations of future policy rates. Depending on the maturity, the implied forward rates are derived from the rates for STINA (Tomorrow-Next Stibor interest-rate swaps) contracts, FRAs (Forward Rate Agreements) or interest-rate swaps.
} 
The period from the start of the publication of the policy-rate path in February 2007 until July 2009 was relatively successful regarding the predictability of policy and the credibility of the Riksbank policy-rate path. In the fall of 2009 there was a period when the market expected the policy rate to be raised earlier than the published path implied. When the policy rate was raised, beginning with the June 2010 meeting, the market expected the policy rate to be raised at a slower pace than the published path. These cases are discussed in more detail in Svensson $(2009,2010)$ and Woodford $(2012,2013)$. Here I will focus on some recent problems.

Regarding predictability and credibility according to (1) and (2) above, the Riksbank has both had successes and great failures in recent years. Figure 3a shows an example of a great success, at the policy meeting in February 2009, and an example of a great failure in figure 3b, at the policy meeting in September 2011. The dashed grey line shows the Riksbank policy-rate path from the previous decision, the dashed black line shows the published new policy-rate path, the solid grey line shows the market policy-rate path the day before the publication, and the solid black line shows the market policy-rate path after the announcement. ${ }^{7}$

Figure 3a shows the very difficult situation at the meeting in February 2009, in the middle of the 20082009 crises. The Swedish economy was in a free fall, the policy rate was reduced by 1 percentage point from 2 percent to 1 percent, and the Riksbank policy-rate path was shifted down even further. The market anticipated this dramatic shift downwards quite well, and after the announcement, the market policy-rate path lined up even closer to the repo-rate path.

[Figure 3]

Figure 3b shows the very different situation in September 2011, when the Riksbank announced a "postponement" of further increases in the policy rate and the steeply rising policy-rate path was shifted somewhat to the right. The discrepancy between the Riksbank path and the market path was exceptionally large. The Riksbank path indicated a rise in the policy rate by about 75 basis points over the next six quarters. The market path was not affected by the announcement and indicated a fall of about 75 basis points over the next six quarters, both before and after the announcement. Ex post, the market policy-rate path was right and the Riksbank policy-rate path was wrong. The Riksbank actually lowered the policy rate by 100 basis points over the next six quarters. ${ }^{8}$

Thus, in September 2011, the Riksbank policy-rate path completely lacked credibility. The market apparently found the Riksbank path to be completely irrelevant. The market path did not move when the new Riksbank path was published. Furthermore, the market was predicting the actual future policy-rate path quite well. The market apparently had a much better idea of what the Riksbank would be doing in the future than what the Riksbank itself communicated. The Riksbank policy-rate path had apparently lost touch with reality.

\footnotetext{
${ }^{7}$ Figures like figure 3 for all (regular) policy meeting from February 2007 through September 2014 are available on my website, larseosvensson.se.

${ }^{8}$ The September 2011 case is further discussed in Woodford (2013).
} 
The exceptionally large discrepancy between the Riksbank's policy-rate path and the market expectations, as well as the fact that the market was much better in predicting the policy rate for the next two years, warrants some closer study. What were the consequences of such a discrepancy between market expectations and the policy-rate path? How does the discrepancy relate to the broader picture of monetary policy in Sweden at the time? What can explain such an unrealistic policy-rate path?

\section{What were the consequences of the September 2011 discrepancy?}

In order to understand the consequences of the discrepancy between market expectations and the policyrate path, we need to note another discrepancy, namely that between the Riksbank forecast for foreign policy rates and the market expectations of future foreign policy rates. This is something that was discussed at several policy meetings, including the September 2011 meeting (Sveriges Riksbank 2011). ${ }^{9}$

In figure 4 below (Sveriges Riksbank 2011, figure 1), the solid grey line shows the Riksbank forecast for (TCW-weighted) foreign policy rates, whereas the dashed grey line shows (TCW-weighted) market expectations of foreign policy rates, extended to a five-year horizon. ${ }^{10} \mathrm{We}$ see that the Riksbank forecast is considerably above market expectations. The solid and dashed black lines in the figure show the Riksbank and market policy-rate paths from figure $3 \mathrm{~b}$ extended to a five-year horizon.

[Figure 4]

The big discrepancy between the Riksbank path and the market path shown in figures $3 \mathrm{~b}$ and 4 means that the market yield curve consistent with the market policy-rate path was very different from the yield curve consistent with a credible Riksbank policy-rate path. The discrepancy between the Riksbank forecast for foreign policy rates and the market expectations of foreign policy rates also means that the market yield curve for foreign interest rates was quite different from the yield curve consistent with the Riksbank forecast. This is illustrated in figure 5 (Sveriges Riksbank 2011, figure 2). The dashed black line shows the Swedish market yield curve, whereas the solid black line shows the yield curve consistent with a credible Riksbank policy-rate path, both extended to a five-year maturity. The dashed grey line shows the foreign market yield curve, whereas the solid grey line shows the yield curve consistent with the Riksbank forecast for foreign policy rates.

[Figure 5]

In figure 5 it can be seen that a Swedish five-year market interest rate (that is, maturing in September 2016) was just over 1.5 percent. But the five-year interest rate compatible with the Riksbank policy-rate path was about 3.2 percent, which is to say about 1.7 percentage points higher. ${ }^{11}$ Furthermore, the foreign five-year market interest rate was about 1.3 percent whereas the foreign five-year interest rate consistent with the Riksbank forecast was about 2.3 percent, that is, about 1 percentage point higher.

\footnotetext{
${ }^{9}$ The Riksbank's published minutes from the policy meetings are attributed and provides - at least for the meetings that I have attended myself - a correct and detailed record of the discussions at the meetings (including figures and tables that I brought to the meetings).

${ }^{10}$ The TCW index (Total Competitiveness Weights) is a geometric index. Its weights are based on the average aggregate flows of processed goods for 21 countries. The weights take account of exports and imports, as well as third-country effects. They are calculated by the IMF.

${ }^{11}$ The yield curve consistent with a credible repo-rate path is adjusted for normal liquidity, credit and term premia.
} 
These discrepancies mean that the Riksbank forecast for inflation and unemployment was inherently inconsistent. The Swedish and foreign financial conditions assumed in the forecast and the models used to construct the forecast for inflation and unemployment were much tighter than the actual Swedish and foreign financial conditions. But inputs such as the exchange rate and other asset prices that are used in the forecast were conditional on the market's lower Swedish and foreign yield curves, not on the Riksbank's higher forecasts of the Swedish and foreign policy rates.

In particular, we realize that the Riksbank forecast for foreign policy rates had the effect of supporting a higher policy-rate path. Suppose that the forecast for foreign policy rates had been shifted down to equal the market expectations of foreign policy rates, that is, shifted down from the solid grey to the dashed grey line in figure 4. For an unchanged Riksbank policy-rate path, the forecasted interest-rate differential between Swedish and foreign interest rates would have increased. This would have induced a forecast of a much stronger Swedish krona, which would have caused forecasted export and employment as well as the forecasted import-price inflation to shift down. Then the forecast for inflation would also have shifted downwards, and that for unemployment would have shifted upwards. Everything else equal, there would have been a strong case for the policy rate and policy-rate path to be shifted downwards. Such a shift down in the policy rate and policy-rate path would have countered these shifts in the forecasts for inflation and unemployment and resulted in forecasts for inflation and unemployment that better stabilized inflation around the target and unemployment around its long-run sustainable rate.

Thus, everything else equal, the high forecast for foreign policy rates served to shift the inflation forecast upwards and shift the unemployment forecast downwards, thereby supporting a high policy-rate path.

That Riksbank inflation forecasts became strongly biased upwards is apparent from figure 4. It shows the Riksbank's CPI inflation forecasts during 2011 and 2012 and the actual outcome of CPI inflation.

[Figure 6]

Obviously, the market did not agree with either the high forecast for foreign policy rates or the high policy-rate path. The market apparently realized that the Riksbank's high policy rate path would bring too strong a krona, with the above consequences, and force the Riksbank to adjust its policy. In discussions that I had with market participants at the time, they indeed did express such views.

As noted, the big discrepancy between the market yield curve and the yield curve consistent with the policy-rate path in figure 4 means that the actual financial conditions in the Swedish economy were much easier in September 2011 than if the policy-rate path had become credible, what one may call the intended financial conditions. Suppose that the market had suddenly started to believe in the high policy-rate path. That is, assume that the market policy-rate path, the dashed black line in figure 4, had shifted up to the solid black line. This means that the dashed black yield curve in figure 5 would have shifted up to the solid black yield curve, which means that a five-year interest rate would have increased by 1.7 percentage points, and the krona would have appreciated considerably. As I argued at the September 2011 meeting (Sveriges Riksbank 2011), it would have been a devastating shock to the Swedish economy if the 
Riksbank policy-rate path had suddenly become credible. It seems that it was the economy's good luck that the Riksbank policy-rate path lacked credibility. ${ }^{12}$

\section{The broader picture of Swedish monetary policy}

The September 2011 decision and policy-rate path were part of a bigger picture. In the summer of 2010, the Riksbank had started a period of policy tightening, in spite of a low forecast for inflation and a high forecast for unemployment. This is discussed in detail in Svensson $(2011,2013)$. It led to CPI inflation dropping to zero and the unemployment rate getting stuck at around 8 percent. Both ex ante and ex post, the policy tightening appears to have been premature.

As can be seen in figure 7, CPI inflation has actually systematically undershot the inflation target in Sweden since the target of 2 percent CPI inflation started to apply in 1995. In spite of this, inflation expectations, including those of the social parties, have been anchored at the target, as can be seen in figure 8. As discussed in detail in Svensson (2015b), the fact that average inflation has undershot the target and inflation expectations has led to about 0.8 percentage point higher average unemployment during 1997-2011, compared to if average inflation had equaled the target.

As discussed in Svensson (2014), according to a counterfactual experiment with the help of the Riksbank's main DSGE model, Ramses, the aggressive leaning against the wind starting in the summer of 2010 has lead to unemployment being about 1.2 percentage point higher in 2013 compared to if the policy rate had been kept unchanged at 0.25 percent from the summer of 2010. The solid black line in figure 9 shows the unemployment rate in Sweden, which has stayed up at around 8 percent after the tightening 2010-2011. The dashed black line shows how unemployment would have developed according to the counterfactual experiment.

[Figure 7]

[Figure 8]

[Figure 9]

The main reason for the leaning against the wind was concerns about increased risks associated with household debt, although this was not expressed very clearly until later. In the press release of July 1 , 2010 (with the June 30 policy decision; Riksbank policy decisions are announced the day after the meeting), there is a paragraph with a somewhat cryptic reference to household debt:

Inflationary pressures are currently low, but are expected to increase as economic activity strengthens. The repo rate now needs to be raised gradually towards more normal levels to attain the inflation target of 2 per cent and at the same time ensure stable growth in the real economy. The Executive Board of the Riksbank has therefore decided to raise the repo rate by 0.25 of a percentage point to 0.5 per cent. Another factor is that household indebtedness has increased significantly in recent years. (Sveriges Riksbank 2010c, italics added.)

\footnotetext{
12 The consequences of the market implementing more expansionary financial conditions than what is consistent with the policy-rate path and apparently intended by the Riksbank are also discussed in Svensson (2011).
} 
However, the inflation forecast in the July 2010 Monetary Policy Report (Sveriges Riksbank 2010b) actually show the CPIF inflation forecast (CPIF inflation is CPI inflation for unchanged mortgage rates) falling significantly below the inflation target except towards the end of the forecasting period when it hits the inflation target from below. The unemployment forecast was high and much above the Riksbank's estimate of a long-run sustainable rate. Also, one could argue that GDP growth needed to be much above normal to remedy the large fall in output during the crisis.

Furthermore, in the minutes from the June 30 meeting, Governor Ingves stated:

Mr Ingves further said that an interest rate increase was also a signal to avoid new financial imbalances from building up and that household indebtedness ought not to rise too much. $\mathrm{Mr}$ Ingves pointed out that this was something he had noted on several earlier occasions. A low interest rate for too long could lead to a troublesome situation beyond the forecast horizon as a result of a credit expansion. It is of course difficult to measure when house prices and the debt/equity ratio are reaching excessively high levels. But this does not mean it is less important to take them into account in monetary policy. By the time we know all the facts, it is often too late to slow down developments, and this often results in large costs to society. (Sveriges Riksbank 2010a, p. 18, italics added).

Thus, a higher policy rate (and a higher policy-rate path) could be seen as a warning signal to households about their debt. The majority of the Executive Board that supported Ingves in this decision was arguably considering a high policy rate more or less an independent target for monetary policy besides inflation and resource utilization. One can say that the majority put more weight on normalizing the policy rate than on normalizing inflation and unemployment.

However, according to estimates later published by the Riksbank (Sveriges Riksbank 2014b), the policyrate effect on real debt and the debt-to-income ratio is very small, not significantly different from zero, and there is no evidence of any long-run effect. As discussed in detail in Svensson (2015a), with these estimates and those of Flodén (2014) and Schularick and Taylor (2012), one can show that the benefits of a higher policy rate, in terms of lower expected future unemployment because of a lower probability of a future crises and a less deep crisis if it would occur, are about 0.4 percent of the cost in terms of higher unemployment the next few years. Thus, the benefits are completely insignificant compared to the costs. For the policy to be justified, the benefits should of course have been more than 100 percent of the cost.

In addition, in the last three years, the price level has fallen about 6 percent below the what households have expected, substantially increasing the households' real debt burden and arguably increasing rather than decreasing any risks associated with household debt (Svensson 2015a).

\section{The New Zealand experience}

The RBNZ has the longest experience of publishing a forecast for the interest rate, in this case the 90-day rate, from June 1997. Figure 10 shows the RBNZ policy rate (the Official Cash Rate), the 90-day rate, and the RNBZ 90-day paths from 1999Q1 to 2014Q3. ${ }^{13}$

\footnotetext{
${ }^{13}$ The RBNZ's publication of its policy instrument has led to some lively debate in the academic and policy circles (Archer 2005, Anderson and Hofman 2009). Moessner and Nelson (2008), one of the earliest empirical studies of the
} 
[Figure 10]

Figure 11 shows the policy-rate and market policy-rate paths (market expectations of future policy rates) from 2004Q1 to 2014Q3.

\section{[Figure 11]}

The New Zeeland experience of successes and failures regarding predictability and credibility is not at all as dramatic as the Swedish one. In particular, there are no failures of the same magnitude as the Swedish September 2011 one. This is not surprising, because the broader picture of monetary policy in New Zealand is quite different from that for Sweden.

Figure 12 shows CPI inflation, a 5-year trailing moving average, and the target midpoint (the midpoint of the target range). The inflation target was changed from 0-2 percent to 0-3 percent in December 1996, and again to 1-3 percent in September 2002, shifting the target midpoint accordingly.

[Figure 12]

Whereas inflation systematically undershot the target in Sweden, in New Zealand it has been a bit on the high side. We see this more clearly in figure 13, where I show the deviation from the target midpoint, a 5year trailing moving average, and the average from 1992, two years after the target was starting to apply. As we can see, inflation has on average overshot the target midpoint by about half a percentage point.

\section{[Figure 13]}

In Sweden, as mentioned, inflation expectations have been anchored at the target, in spite of inflation on average undershooting the target. Svensson (2015b) shows that this has led to higher average unemployment than if inflation had on average equaled the target. If inflation expectations in New Zealand had been anchored at the target midpoint, by the same logic we might have seen average unemployment actually being lower than if inflation had on average equaled the target midpoint. However, as is apparent from figure 14, 5-year moving averages of inflation expectations do not deviate much from those of inflation, so given this there is no reason to expect any impact on average unemployment from inflation overshooting the target. In other words, this indicates that inflation expectations have adjusted to make the long-run Phillips curve is vertical for New Zealand, in contrast to what I have shown during 1997-2011 for Sweden in Svensson (2015b).

However, we do see inflation undershooting the target midpoint during the last few years, although much less than in Sweden. Furthermore, figure 9 indicates that the unemployment performance is better in New Zealand, and in particular unemployment has come down recently whereas it has stayed up much higher in Sweden.

[Figure 14]

RBNZ's interest-rate path, found a statistically significant impact of the RBNZ forecasts on market interest rates. Detmers and Nautz (2012) extends on Moessner and Nelson (2008) and found that the information content of interest rate projections depends on the forecast horizon and on the degree of uncertainty about the economic outlook. Bergstrom and Karagedikli (2013) found that as long as the economic agents interpret the forecasts by the RBNZ as conditional forecasts as opposed to commitments, the RBNZ forecasts help them improve their forecasts for other macrovariables. 
Before looking at some specific dates, we might note that the comparison of the new RBNZ 90-day path and the market policy-rate paths is complicated by the circumstance that the latter refers to market expectations of the policy rate, the Official Cash Rate. The average 90-day rate during the period 1999Q1 to $2014 \mathrm{Q} 3$ is 0.24 percentage points higher than the average policy rate. This might be interpreted as a rough estimate of an average 90-day premium over the OCR. According to the pure expectations hypothesis, the 90-day rate should equal a leading 90-day moving average of the expected policy rate. This means that the 90-day rate should exceed the policy rate by more (less) if the policy rate is expected to rise (fall) over the next 90 days. Taking into account the average premium, the spread between the 90 day rate and the policy rate would then exceed or fall short of 0.24 percentage points according to whether the market policy rate is upward- or downward-sloping. As we see in figure 10, the spread indeed seems to be on average larger when the policy rate is rising than when it is falling.

Furthermore, the comparison between the new and old policy-rate path is not as straightforward as in the Riksbank case. This is because the RBNZ publishes a 90-day path only after every second of its eight meetings per year, whereas the Riksbank publishes a policy-rate path after each of its six meetings per year. Thus, the shift from the old to the new RBNZ 90-day path is less informative in the New Zealand, and it is difficult to assess how much of this shift was implicit at the previous meeting when no path was published.

If we look at some specific dates, figure 15, from March 2005, is an example of a relative success, I believe. The RBNZ had in January 2005 kept its policy rate unchanged at 6.5 percent. In March, it increased the policy rate by 0.25 percentage points to 6.75 percent and shifted up the relatively flat 90 -day path relative to the path it had published in December. ${ }^{14}$

[Figure 15]

We see from the solid grey line that the increase in the policy rate and the new 90-day path was relatively well anticipated. After the announcement, the market policy rate shifted up a little, remaining roughly parallel to the new 90-day path, indicating relatively good credibility of the 90-day path.

Figure 16 shows another example under the difficult circumstances in the beginning of the global financial crises, somewhat similar to the Riksbank experience in figure 3a. The RBNZ had lowered the policy rate by 1.5 percentage points from 5 to 3.5 percent in January 2009 (without publishing a new policy-rate path). In March, it lowered the policy rate by another 0.5 percentage points to 3 percent, and published a new 90-day path. The solid grey line shows that this was well anticipated, although the market might have anticipated a somewhat larger cut. After the announcement, the market policy-rate path shifted up a bit, indicating reasonably good credibility of the new 90-day path.

[Figure 16]

\footnotetext{
${ }^{14}$ Figures like figure 15 for each quarter from March 2004 through March 2014 are available on my website, larseosvensson.se.
} 
Figure 17, from December 2009, shows an example where, before and after the announcement, the market policy-rate path indicates tighter policy than the RBNZ 90-day path. Because the market policy-rate path is upward sloping, the corresponding market 90-day path (the path of market expectations of future 90-day rates) would be more than 0.24 percentage points above the market policy-rate path, putting it significantly above the RBNZ 90-day path. Thus, on this occasion, the actual financial conditions were substantially tighter than the intended ones.

[Figure 17]

Figure 18, from December 2011, gives an example of how the published 90-day path has low credibility and that the actual financial conditions are much easier than the intended. Furthermore, figure 19 shows that the market seemed to anticipate quite well that a lower policy-rate path and easier intended policy would be implemented in March 2012. During this time, all the action was in the RBNZ 90-day path and market policy-rate paths, because the policy rate was kept unchanged at 2.5 percent.

[Figure 18]

[Figure 19]

In figure 20, from December 2013, we again see an example of the RBNZ 90-day path being well anticipated before the announcement and quite credible after the announcement.

[Figure 20]

\section{The U.S. experience}

The FOMC has used verbal forward guidance about its likely future policy settings at various times in the past. As discussed by Williams (2012), in the summer of 2011 that forward guidance became more explicitly a tool to influence expectations of the future path of the policy rate and thereby longer-term interest rates and financial conditions. As an example, in August 2011, the FOMC stated that it "anticipates that economic conditions... are likely to warrant exceptionally low levels for the federal funds rate at least through mid-2013." This statement thus communicated that the FOMC was likely to keep the federal funds rate near zero for at least another two years, longer than many private-sector economists had been thinking. As a result, longer-term Treasury yields fell between 0.1 and 0.2 percentage points, a substantial fall.

In January 2012, the FOMC started to provide more specific information about FOMC participants' assessments of the appropriate future policy-rate setting, in the form of the dot plot in the Summary of Economic Projections (SEP) (Federal Open Market Committee 2012b, figure 2, lower panel). It is shown in figure 21 below (the dashed black $d$ has been added and is discussed below). Each dot in the lower panel indicates the value (rounded to the nearest $1 / 4$ percent) of an individual FOMC participant's judgment of the appropriate level of the target federal funds rate at the end of the specified calendar year or over the longer run. In figure 2 in SEP, the upper panel (not shown in figure 21) shows the number of FOMC participants who judge that, under appropriate monetary policy and in the absence of further shocks to the economy, the first increase in the target federal funds rate from its current range of 0 to $1 / 4$ percent will occur in the specified calendar year. This upper panel shows that the median of the participants' assessments in January 2012 of the date of the first rate increase was sometime in 2014. 
From this information and the dot plot one can construct the participants' median policy-rate path as the dashed black line in figure 21. One can interpret this policy-rate path as the result of a hypothetical simultaneous vote among the participants about the appropriate federal funds target at the end of each specified year. Furthermore, I let the median of the assessments of the date of the first rate increase in 2014 be represented by an assumed such date in mid-2014. (Note that the year labels on the horizontal axis in figure 21 refer to the end of the specified year, so mid-2014 corresponds to a point between the labels 2013 and 2014 in the figure.)

The FOMC participants consist of the Federal Reserve Board members and the twelve Federal Reserve Bank presidents. The FOMC members consist of the voting subset of the FOMC participants, that is, the Federal Reserve Board members and the seven voting Federal Reserve Bank president. The median of the members' assessments is arguably more relevant for actual policy decisions than the median of the participants' assessment. Furthermore, one may want to take account of the fact that different Federal Reserve Bank presidents vote each year. However, the information in the dot plot does not allow the median of the members' assessment to be calculated. A study of FOMC participants' speeches and announcements would allow several of the dots to be associated with specific members and go some way towards the calculation of the median of members' assessment. Furthermore, some members' vote, in particular the Chair's, may carry more weight than the other votes. A further refinement could take that into account, if the corresponding dots could be identified.

Furthermore, the dot plot reports the FOMC participants' individual assessments of the appropriate future policy-rate setting, not the committee's joint assessment. ${ }^{15}$ Similarly, the plots with real GDP growth, unemployment and PCE inflation in the SEP report the central tendencies and ranges of each participant's individual projection based on the his or her assessment of appropriate monetary policy. Thus, the SEP does not report a joint committee forecast of inflation, unemployment, and the policy rate similar to the forecasts reported by the Riksbank or the RBNZ. This obviously means that the median projections of inflation, unemployment, and the policy rate in the SEP may be less internally consistent than the forecasts reported by the Riksbank and the RBNZ.

[Figure 21]

Figure 22 shows the federal funds target (plotted at 0.25 percent, the upper limit of the range 0 to 0.25 percent) up to early 2015, the policy-rate path of January 2012 constructed as above, and the market policy-rate paths the day before and after the announcement. (Note that the year labels on the horizontal axis in figure 22 refer to the beginning the specified year, so mid-2014 here corresponds to a point between the labels 2014 and 2015 in the figure.) The market policy-rate paths are constructed from overnight index swaps (OIS) rates for the end of the specified year. We see that this first dot plot of January 2012 implies a median policy-rate path that was reasonably well anticipated by the market and reasonably credible with the market after the announcement. ${ }^{16}$

[Figure 22]

\footnotetext{
${ }^{15}$ Also, because the dots in the dot plot are not connected, the dot plot does not report each participant's assessment of the appropriate path of the policy rate, only the appropriate separate level at the end of each year.

${ }^{16}$ See Bauer and Rudebusch (2014) for estimates of the market expectations of the date of the first rate increase.
} 
After this January 2012 publication, the FOMC have published these dot plots in the SEP in March, June, September, and December each year, that is, five plots in 2012 and four plots per year thereafter. An examination of the policy-rate paths and the market policy-rate paths before and after the announcement show that up through March 2013, the market expectations for the policy rate at the end of 2015 were somewhat below the FOMC median policy rate. ${ }^{17}$ After the so-called "taper tantrum" in May 2013, market expectations shifted up and were well aligned with the policy-rate path from June through December 2013. Figure 23 shows the new FOMC policy-rate path and the market policy-rate paths before and after the announcement in December 2013 as well as the old policy-rate path of September 2013. The market anticipated the new policy-rate path very well and the new policy-rate was highly credible after publication.

[Figure 23]

In March 2014, the policy-rate path was shifted up, but market expectations stayed lower than the policyrate path. This discrepancy between the FOMC's median policy-rate path and market expectations increased over the year and was quite large at the end of the year, in December 2014, as is shown in figure $24 .{ }^{18}$

[Figure 24]

As we can see, the December 2014 FOMC policy-rate path reached a little above 3.5 percent at the end of 2017, whereas the OIS rate for the end of 2017 was a little below 2 percent, more than 150 basis points below the FOMC policy-rate path. This large discrepancy between the participants' median policy-rate path and the market policy-rate path has been much noted and discussed recently (for instance, Christensen and Kwan 2014, Dudley 2015, Fleming and MacKenzie 2015, Wessel 2015, and Yellen 2015).

Possible explanations suggested for the discrepancy include that the market may judge that some of the highest dots belong to non-voting participants and that the Chair's arguably more weighty dots may be below the median.

Figure 25 shows the December 2014 dot plot together with the median policy-rate path and the market policy-rate path as of December 2014 (the paths are plotted under the convention that the location of the year labels correspond to the end of the specified year, so mid 2014 corresponds to the midpoint between the labels 2014 and 2015). We see that all dots for the end of 2017 except the lowest dot lie well above the market expectations (the OIS rate in December 2014 after publication, for the end of 2017). Thus, the discrepancy cannot be explained by the market inferring that the median of the voting members' assessments would be lower than that of the participants' assessments, or that a weighted median with more weight for the Chair would be lower (except in the extreme case that the lowest dot is considered to be the Chair's and all the weight is given to that one).

[Figure 25]

\footnotetext{
${ }^{17}$ Figures like figure 22 for all publication dates from January 2012 through March 2015 are available on my website, larseosvensson.se.

${ }^{18}$ From September 2014, the participants' assessments in the dot plot are rounded to the nearest $1 / 8$ percent instead of the nearest $1 / 4$ percent, making the policy-rate start at $1 / 8$ percent instead of $1 / 4$ percent.
} 
It may also be the case that the market is more pessimistic about the outlook for the U.S. economy than the FOMC participants, or that the market's estimate of the neutral (natural, equilibrium) interest rate is lower than the FOMC participants'. Federal Reserve Board Chair Yellen (2015) observes that many market participants appear to be more pessimistic than the FOMC participants about the outlook for the U.S. economy and notes that respondents to the Survey of Primary Dealers in late January thought that there was a 20 percent probability that, after the date of the first rate increase, the federal funds rate would fall back to zero sometime at or before late 2017 (Federal Reserve Bank of New York, Markets Group 2015). She also notes that the remarkably low level of long-term government bond yields in advanced economies suggest that financial markets place considerable odds on adverse scenarios that would necessitate a lower and flatter path for the federal funds rate than envisioned in the FOMC participants' projections.

The fact that market expectations are lower than the FOMC's policy-rate path implies that the market yield curve is lower than a yield curve consistent with the FOMC's forward guidance. As discussed above for Sweden and New Zealand, this means that the actual monetary policy implemented by the market is more expansionary than the monetary policy intended by the FOMC. Furthermore, forward rates at long time horizons are significantly lower than the FOMC's median longer-run policy rate at 3.75 percent. Federal Reserve Bank President Dudley (2015) has concluded that this may warrant a more aggressive path of policy normalization: ${ }^{19}$

$[\mathrm{O}]$ ne significant conundrum in financial markets currently is the recent decline of forward shortterm rates at long time horizons to extremely low levels-for example, the 1-year nominal rate, 9 years forward is about 3 percent currently. My staff's analysis attributes this decline almost entirely to lower term premia. In this case, the fact that market participants have set forward rates so low has presumably led to a more accommodative set of financial market conditions, such as the level of bond yields and the equity market's valuation, that are more supportive to economic growth. If such compression in expected forward short-term rates were to persist even after the FOMC begins to raise short-term interest rates, then, all else equal, it would be appropriate to choose a more aggressive path of monetary policy normalization as compared to a scenario in which forward short-term rates rose significantly, pushing bond yields significantly higher.

Because at the time of writing (March 2015) inflation and inflation forecasts are low relative to the target and unemployment and unemployment forecasts are not very low relative to a long-run sustainable unemployment rate (especially when possible additional slack is indicated by a involuntary part-time work and a cyclical part of the participation rate), it seems that the U.S. economy is far from any risks of overheating (Evans 2015). Given this it may perhaps be a good thing and contribute to better target achievement if actual monetary policy is looser than the FOMC participants' policy-rate path.

\footnotetext{
${ }^{19}$ Dudley is making these comments in the context of his criticism of a mechanical instrument rule such as a Taylor rule. He mentions the discrepancy between the FOMC's forward guidance and market expectations as an example of the loose relation between the federal funds rate, financial conditions, and economic outcomes, making the use of a mechanical instrument rule inappropriate. I have criticized Taylor rules and other instrument rules myself (for instance, in Svensson 2003), arguing that the use of judgments is a necessary input in good monetary policy. This precludes the reliance on mechanical instrument rules such as the Taylor rule and instead justifies the use of targeting rules and forecast targeting (choosing the policy rate and the policy-rate path such that the forecasts of the target variables "look good", where "looking good" means stabilizing inflation around the inflation target and resource utilization around a long-run sustainable rate.
} 
As shown in figure 26, at the FOMC meeting in March 2015, the median FOMC policy-rate path shifted down considerably, that is, towards the market policy-rate path. The market policy-rate path also shifted down, but less. Thus, the discrepancy between the FOMC path and the market path shrank a bit, but it remained substantial. The fact that two FOMC members known to favor higher policy rates had retired from the FOMC before the March meeting may explain part of the shift down but not all. Somewhat weaker data has probably contributed. Nevertheless, the market is still expecting and implementing a substantially more expansionary monetary policy than is consistent with the FOMC policy-rate path.

\section{Conclusions}

I believe there are good reasons why forward guidance in the form of publishing a policy-rate path has become a normal part of flexible inflation targeting for several central banks. These reasons have been listed above under the headings of transparency, effectiveness, informativeness, justification, and accountability of monetary policy. In this paper, I have assessed the predictability of monetary policy and the credibility of the policy-rate path for the Riksbank, the RBNZ, and the Federal Reserve. Here, predictability of monetary policy refers to the extent to which the market anticipates the central banks policy-rate path, and credibility of the policy-rate path refers to the extent to which market expectations line up with central-bank policy-rate path after the publication.

The Swedish experience of publishing a policy-rate path has been quite dramatic and special in recent years. In spite of very difficult circumstances during the crisis, in February 2009, the market anticipated a big downward shift in policy-rate path quite well, and after publication the market expectations of the future policy rate lined up quite well with the published policy-rate path. In contrast, in September 2011, the Riksbank published a high and increasing policy-rate path that was completely disregarded by the market. Market expectations before and after publication instead indicated a fall in the policy rate, expectations that predicted the actual outcome of the policy rate very well. This means that the actual monetary policy that the market implemented through its actual yield curve was much easier than intended monetary policy, the yield curve consistent with the Riksbank policy rate path. The market apparently predicted that the Riksbank would have to make a major policy shift towards easier policy.

This very special situation can be understood with reference to the aggressive leaning against the wind and policy tightening that the Riksbank initiated in June/July 2010, because of concerns about household debt. A high policy rate and policy-rate path effectively got priority over the standard objectives of flexible inflation targeting, that is, stabilizing inflation around the inflation target and resource utilization around its long-run sustainable path. High difficult-to-justify Riksbank forecasts of foreign policy rates contributed to supporting a high policy-rate path but caused a strong positive bias in Riksbank inflation forecasts. As a result of the Riksbank's leaning against the wind, inflation had fallen much below the target and unemployment remained high and much above its long-run sustainable rate. The Riksbank was then forced to lower the policy rate all the way down to the negative range.

The New Zealand experience is much less dramatic. Monetary policy has been better focused on the standard monetary policy objectives. In many cases the market has anticipated the RBNZ policy-rate path quite well, and market expectations have lined up well with the path after publication. There are cases when the market has implemented a substantially tighter policy than the one consistent with the RBNZ policy-rate path. There are also cases when the market has implemented a much easier policy, for instance 
in December 2011. Furthermore, on that occasion the market seems to have been well ahead of the RBNZ, in the sense that the RBNZ in March 2012 followed the market by shifting down its policy-rate path to line up well with the market expectations.

The U.S. experience of a published policy-rate path in the form of the dot plot is quite short, starting in January 2012. The dot plot reports each FOMC participant's assessment of appropriate monetary policy rather than a joint committee projection. If the median of the dot plot nevertheless is interpreted as an approximation to a joint committee projection and an FOCM policy-rate path, the U.S. experience includes cases where the market has anticipated the FOMC path quite well and market expectations have lined up well with the path after publication. More recently, the market path lies significantly below the FOMC path and the market is thus implementing a significantly easier policy than consistent with the FOMC path. The reasons for this discrepancy between the FOMC and market paths have been much discussed but no consensus about the reasons have been reached at the time of writing. Thus far during the short U.S experience, there is no case when the actual financial conditions implemented by the market have been tighter than what is consistent with the FOMC participant's policy-rate path.

Even though the New Zealand and U.S. experiences are less dramatic than the Swedish one, it may certainly be interesting and worthwhile do examine more closely what particular circumstances explains when and when not the policy-rate path was well anticipated, and when and when not the published path was credible after publication. This may help in improving the effectiveness and informativeness of the policy-rate path. 


\section{References}

Archer, David (2005), "Central Bank Communication and the Publication of Interest Rate Projections," paper for a Sveriges Riksbank Conference on Inflation Targeting, www.riksbank.se.

Andersson, Magnus, and Boris Hofman (2009), "Gauging the Effectiveness of Quantitative Forward Guidance: Evidence from Three Inflation Targeters,” ECB Working Paper No. 1098, www.ecb.eu.

Bergstrom and Karagedikli (2013), "Interest Rate Conditioning Assumption: Investigating the Effects of Central Bank Communication in New Zealand, working paper, Reserve Bank of New Zealand, www.rbnz.govt.nz.

Bauer, Michael D., and Glenn D. Rudebusch (2014), "Monetary Policy Expectations at the Zero Lower Bound,” Working Paper 2013-18, Federal Reserve Bank of San Francisco, www.frbsfr.org.

Christensen, Jens H.E., and Simon Kwan (2014), “Assessing Expectations of Monetary Policy,” FRBSF Economic Letter 2014-27, September 8, www.frbsfr.org.

Federal Open Market Committee (2012a), Statement on Longer-Run Goals and Monetary Policy Strategy, January 25, www.federal.reserve.gov.

Federal Open Market Committee (2012b), Summary of Economic Projections, January 2012, www.federal.reserve.gov.

Detmers, Gunda-Alexandra, and Dieter Nautz (2012), "The Information Content of Central Bank Interest Rate Projections: Evidence from New Zealand," Economic Record 88, 323-329.

Dudley, William C. (2015), "Remarks at the 2015 U.S. Monetary Policy Forum," speech on February 27, www.ny.frb.org.

Evans, Charles (2015), "Low Inflation Calls for Patience in Normalizing Monetary Policy," speech on March 4, 2015, www.chicagofed.org.

Federal Reserve Bank of New York, Markets Group (2015), Responses to Survey of Primary Dealers, January 2015, www.newyorkfed.org.

Fleming, Sam, and Michael MacKenzie (2015), "Inflation Expectations Set to Ease Fed Fears," Financial Times, March 5, www.ft.com.

Flodén, Martin (2014), "Did Household Debt Matter in the Great Recession?," supplement to blog post on Ekonomistas.se, martinfloden.se.

Gosselin, Pierre, Aileen Lotz, and Charles Wyplosz (2008), "The Expected Interest Rate Path: Alignment of Expectations vs. Creative Opacity," International Journal of Central Banking 4(3), 145-185.

Jansson, Per, and Anders Vredin (2003), "Forecast-Based Monetary Policy: The Case of Sweden," International Finance 6(3), 349-380.

Leitemo, Kai (2003), "Targeting Inflation by Constant-Interest-Rate Forecasts," Journal of Money, Credit and Banking 35(4), 609-626. 
Moessner, Richild, and William R. Nelson (2008), "Central Bank Policy Rate Guidance and Financial Market Functioning," International Journal of Central Banking 4(4), 193-226.

Schularick, Moritz, and Alan M. Taylor (2012), "Credit Booms Gone Bust: Monetary Policy, Leverage Cycles, and Financial Crises, 1870-2008," American Economic Review 102, 1029-1061.

Svensson, Lars E.O. (1998), "Inflation Targeting in An Open Economy: Strict or Flexible Inflation Targeting," Victoria Economic Commentaries 15-1 (March 1998).

Svensson, Lars E.O. (2001), "Independent Review of the Operation of Monetary Policy in New Zealand: Report to the Minister of Finance," www.larseosvensson.se/revnzmp/.

Svensson, Lars E.O. (2003), "What Is Wrong with Taylor Rules? Using Judgment in Monetary Policy through Targeting Rules," Journal of Economic Literature 41, 426-477.

Svensson, Lars E.O. (2006), "The Instrument-Rate Projection under Inflation Targeting: The Norwegian Example," in Stability and Economic Growth: The Role of Central Banks, Banco de Mexico, 2006, 175198.

Svensson, Lars E.O. (2009), "Transparency under Flexible Inflation Targeting: Experiences and Challenges," Sveriges Riksbank Economic Review 1/2009, 5-44.

Svensson, Lars E.O. (2010), "Policy Expectations and Policy Evaluations: The Role of Transparency and Communication," Sveriges Riksbank Economic Review 1/2010, 43-78.

Svensson, Lars E.O. (2011), "Practical Monetary Policy, Examples from Sweden and the United States," Brookings Papers on Economic Activity, Fall 2011, 289-332, www.brookings.edu.

Svensson, Lars E.O. (2013), "Some Lessons from Six Years of Practical Inflation Targeting," Sveriges Riksbank Economic Review 2013:3, 29-80.

Svensson, Lars E.O. (2014), “Unemployment and Monetary Policy - Update for the Year 2013," blog post, larseosvensson.se.

Svensson, Lars E.O. (2015a), "Inflation Targeting and Leaning Against the Wind," forthcoming in South African Reserve Bank (2015), Fourteen Years of Inflation Targeting in South Africa and the Challenge of a Changing Mandate: South African Reserve Bank Conference Proceedings 2014. Pretoria: South African Reserve Bank. Available at www.larseosvensson.se.

Svensson, Lars E.O. (2015b), “The Possible Unemployment Cost of Average Inflation below a Credible Target," American Economic Journal: Macroeconomics 7(1), 258-296.

Svensson, Lars E.O., and Michael Woodford (2005), "Implementing Optimal Policy through InflationForecast Targeting," (with Michael Woodford, Columbia University), in Bernanke, Ben S., and Michael Woodford, eds. (2005), The Inflation-Targeting Debate, University of Chicago Press, 19-83.

Sveriges Riksbank (2010a), "Minutes of the monetary policy meeting, no. 3, June 30, 2010," www.riksbank.se. 
Sveriges Rikbank (2010b), Monetery Policy Report July 2010, www.riksbank.se.

Sveriges Riksbank (2010c), Press Release, July 1, 2010, www.riksbank.se.

Sveriges Riksbank (2011), "Minutes of the monetary policy meeting, no. 4, September 6, 2010,"

www.riksbank.se.

Sveriges Riksbank (2014a), Account of Monetary Policy 2013, www.riksbank.se

Sveriges Riksbank (2014b), "The Effects of Monetary Policy on Household Debt," box in Monetary

Policy Report February 2014, www.riskbank.se.

Vickers, John (1998), "Inflation Targeting in Practice: The U.K. Experience," Bank of England Quarterly

Bulletin, November 1998.

Wesssel, David (2015), "What's Behind the Fed's Credibility Gap on Interest Rates," Wall Street Journal, February 6, blogs.wsj.com.

Williams, John C. (2012), “The Federal Reserve's Unconventional Policies," FRBSF Economics Letter 2012-34, November 12, www.frbsf.org.

Woodford, Michael (2005), "Central Bank Communication and Policy Effectiveness," in The Greenspan Era: Lessons for the Future, A Symposium Sponsored by the Federal Reserve Bank of Kansas City, Federal Reserve Bank of Kansas City, 399-474.

Woodford, Michael (2007), "The Case for Forecast Targeting as a Monetary Policy Strategy," Journal of Economic Perspectives 21(4), 3-24.

Woodford, Michael (2012), "Methods of Policy Accommodation at the Interest-Rate Lower Bound," in The Changing Landscape: A Symposium Sponsored by the Federal Reserve Bank of Jackson City, Federal Reserve Bank of Kansas City, 185-288.

Woodford, Michael (2013), "Forward Guidance by Inflation-Targeting Central Banks," Sveriges Riksbank Economic Review 2013:3, 81-120.

Yellen, Janet (2015), "Normalizing Monetary Policy: Prospects and Perspectives," speech on March 27, www.federalreserve.gov. 
Figure 1. The Riksbank policy rate and policy-rate paths Percent

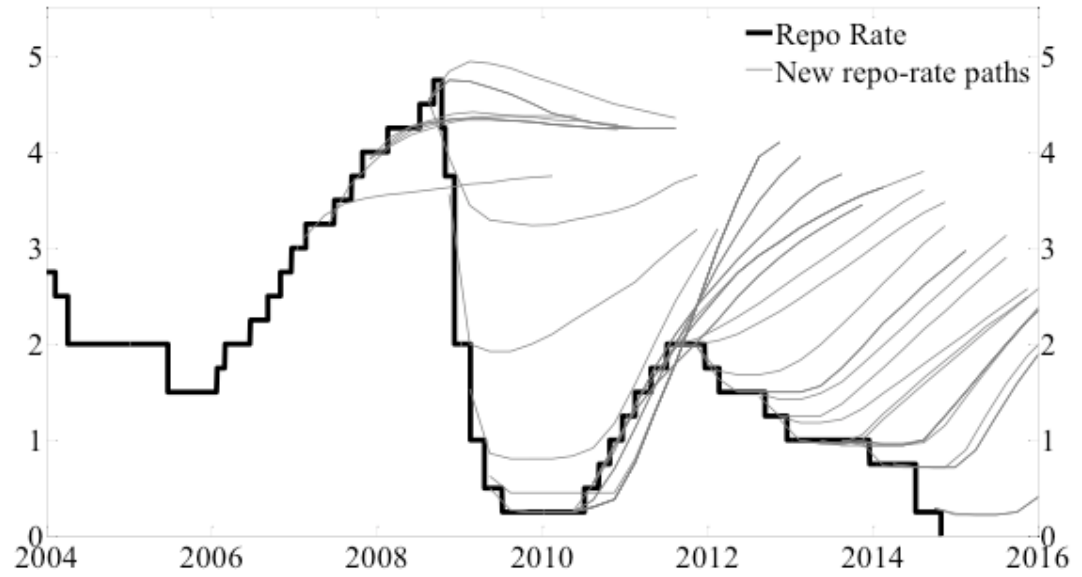

Source: The Riksbank.

Figure 2. The Riksbank policy rate and market policy-rate paths Percent

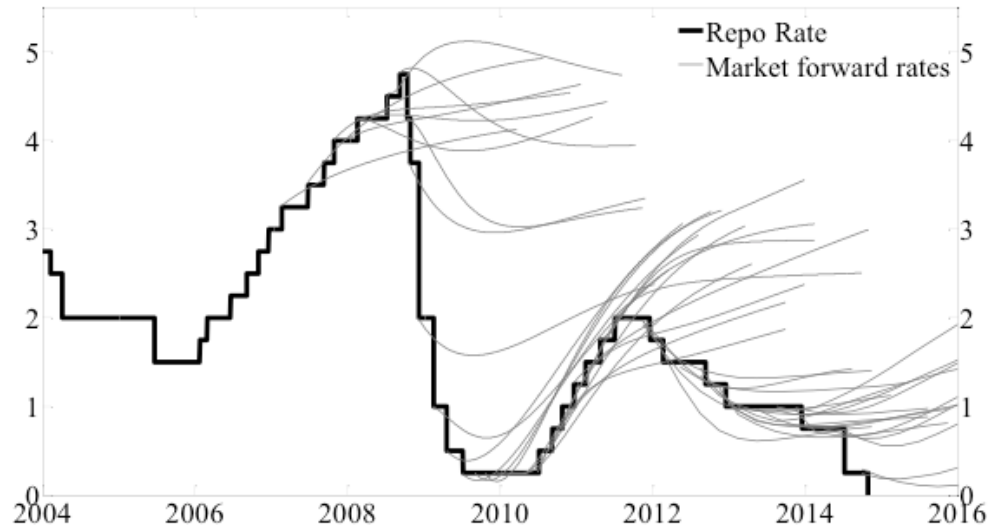

Source: The Riksbank 
Figure 3. The policy rate, the Riksbank policy-rate path, and the market policy-rate path before and after the announcement

a. February 2009

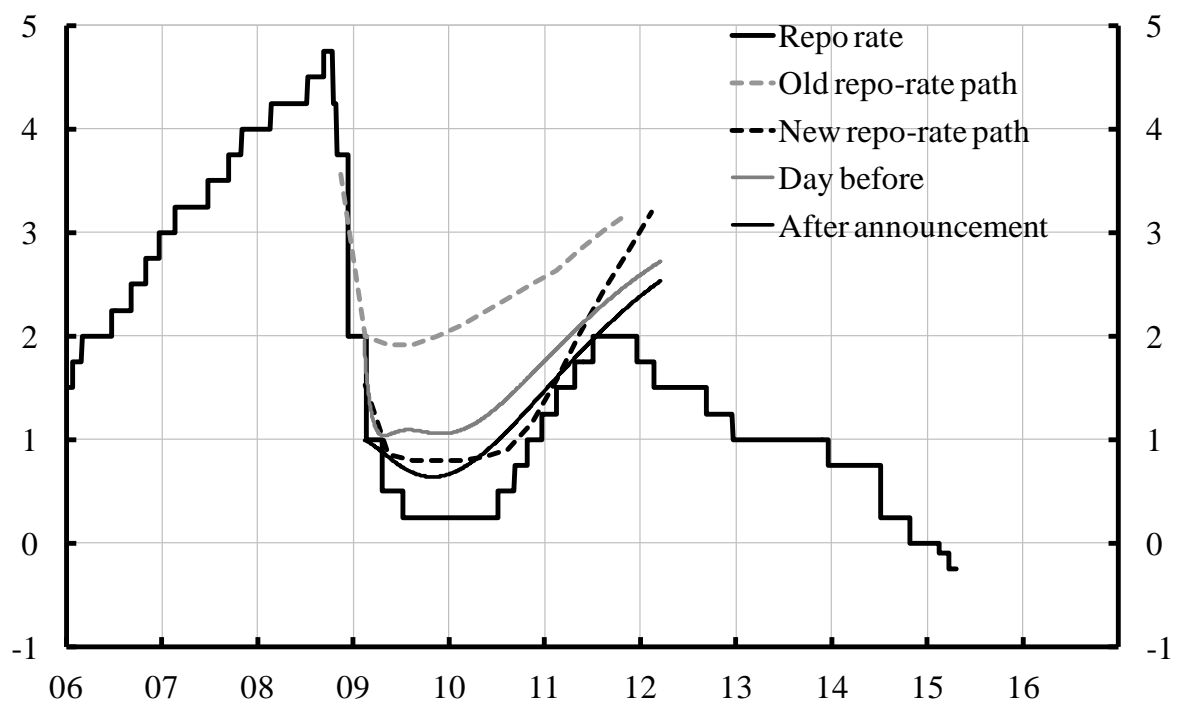

b. September 2011

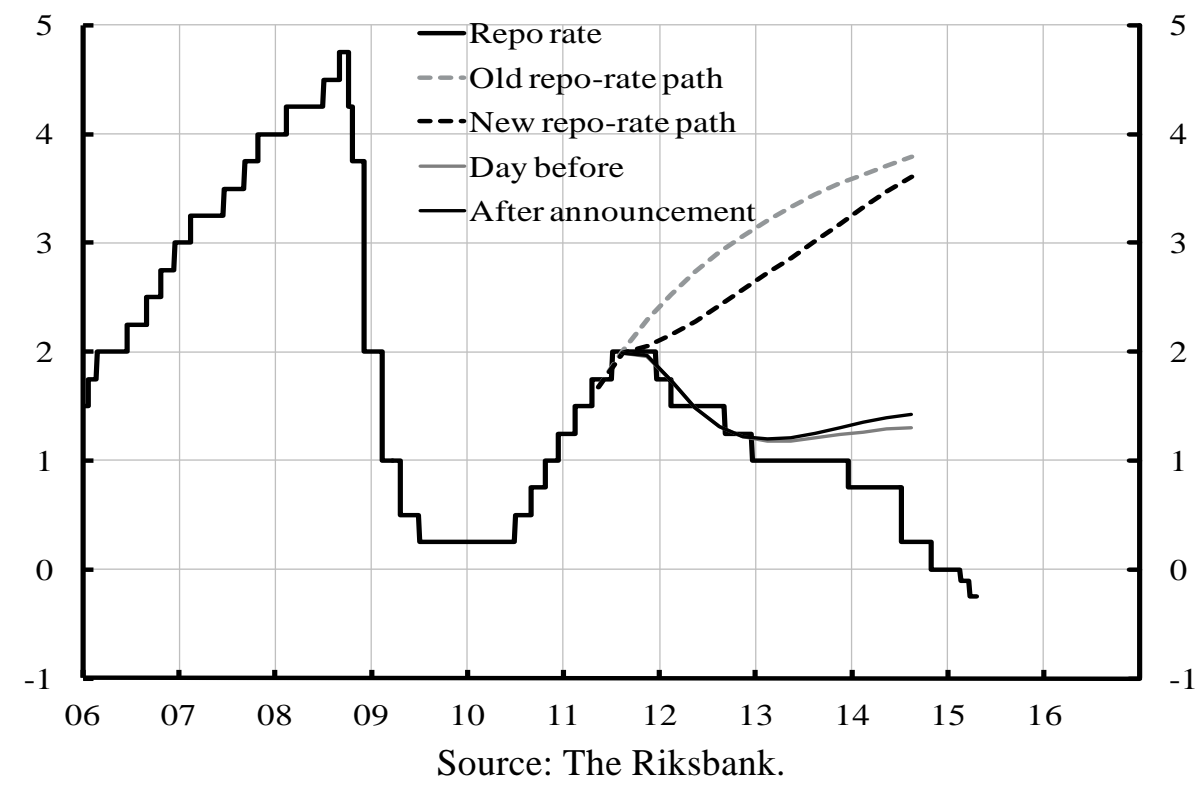


Figure 4 Riksbank and market policy-rate paths, Riksbank forecast for foreign policy rates, and market expectations of foreign policy rates, September 2011

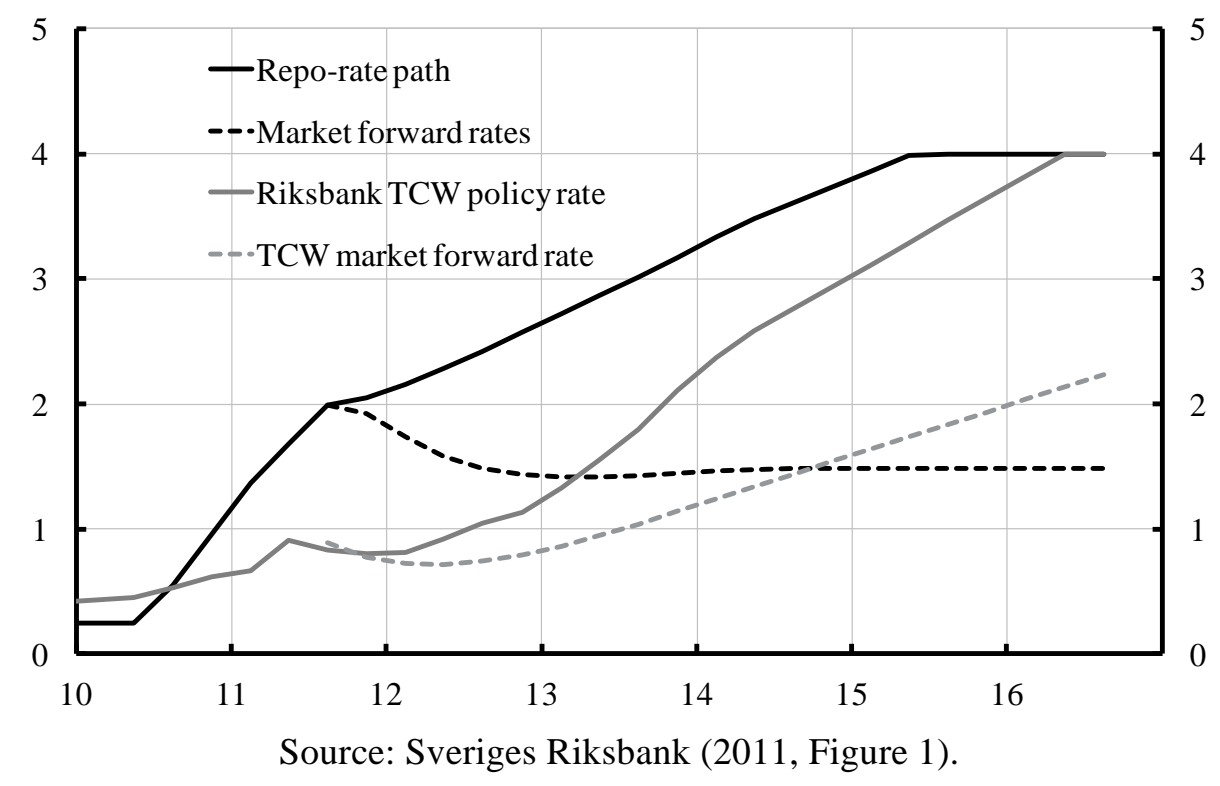

Figure 5. Actual Swedish and foreign yield curves and yield curves consistent with Riksbank forecasts, September 2011

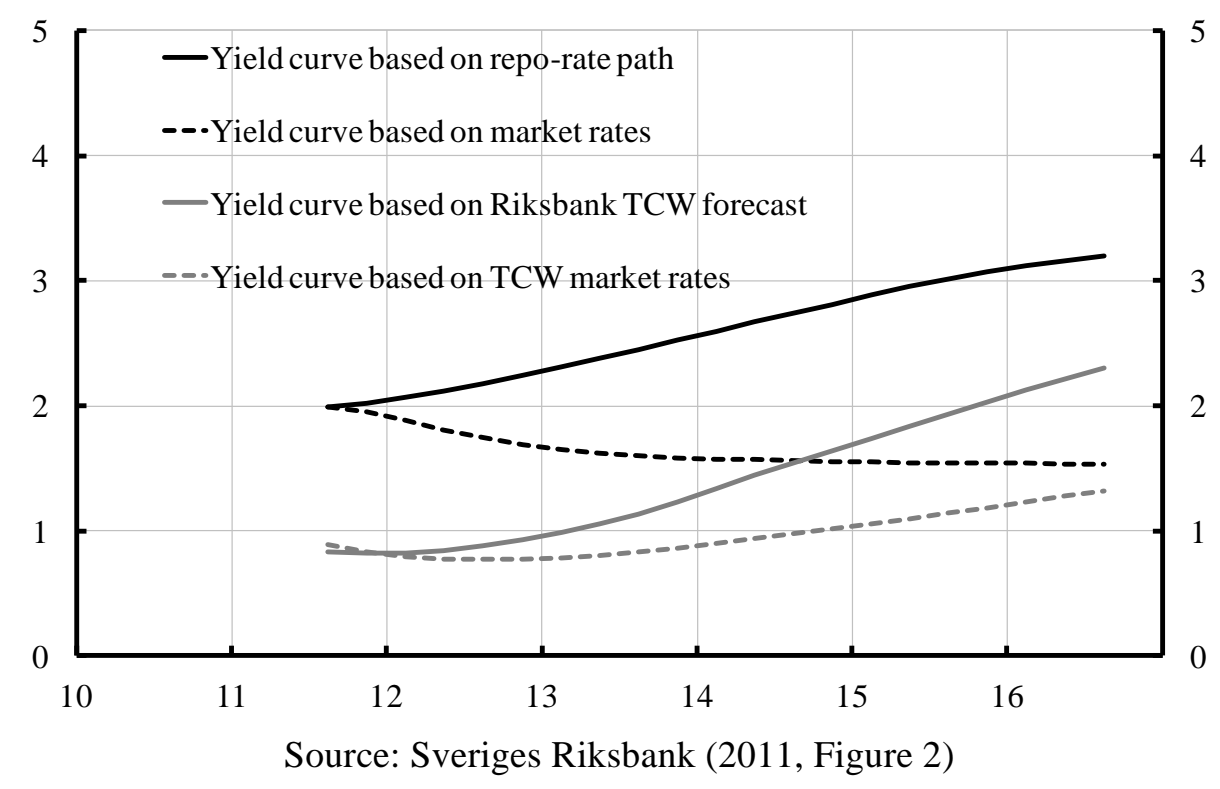


Figure 6. Riksbank CPI forecasts during 2011 and 2012 and the outcome

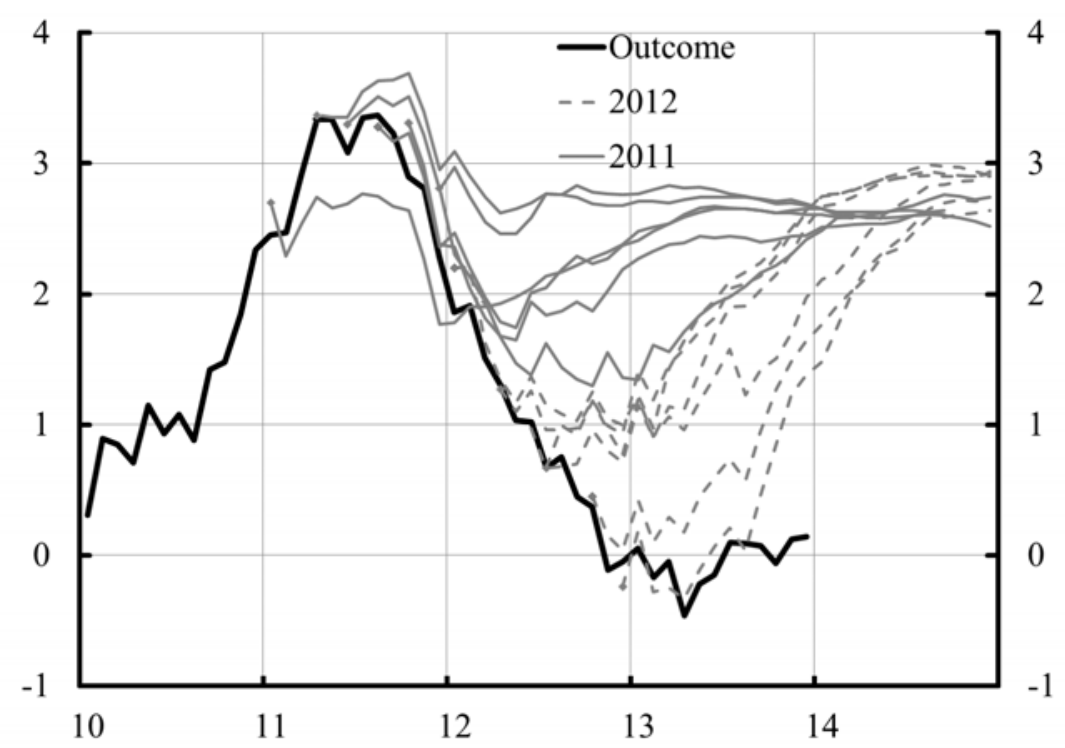

Note: The grey and black thin lines show the Riksbank's forecasts 2011-2012.

The marks show the starting point of each forecast and may therefore deviate from the latest outcome at that point in time.

Source: Statistics Sweden and the Riksbank (Figure 2.6 of Sveriges Riksbank (2014a)).

Figure 7. Annual CPI inflation, 5-year moving averages, and average from 1995, Sweden

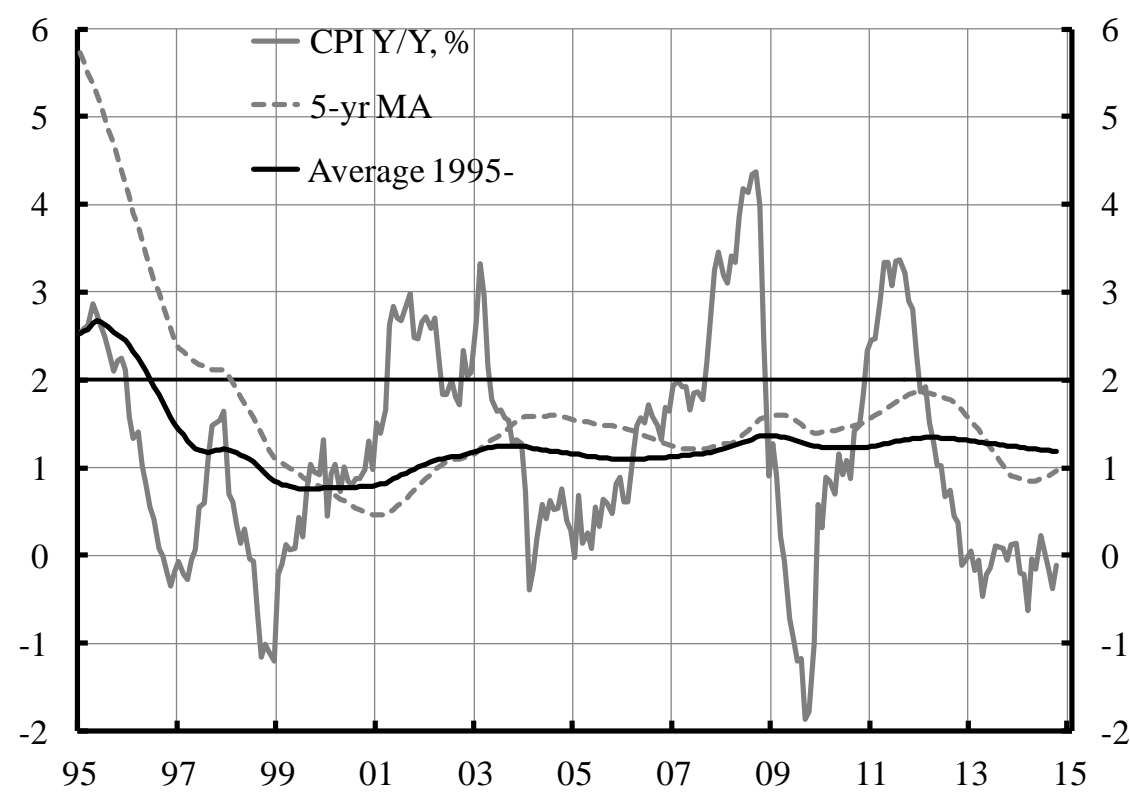

Source: Statistics Sweden. 
Figure 8. CPI inflation and inflation expectations 2 years from now, Sweden

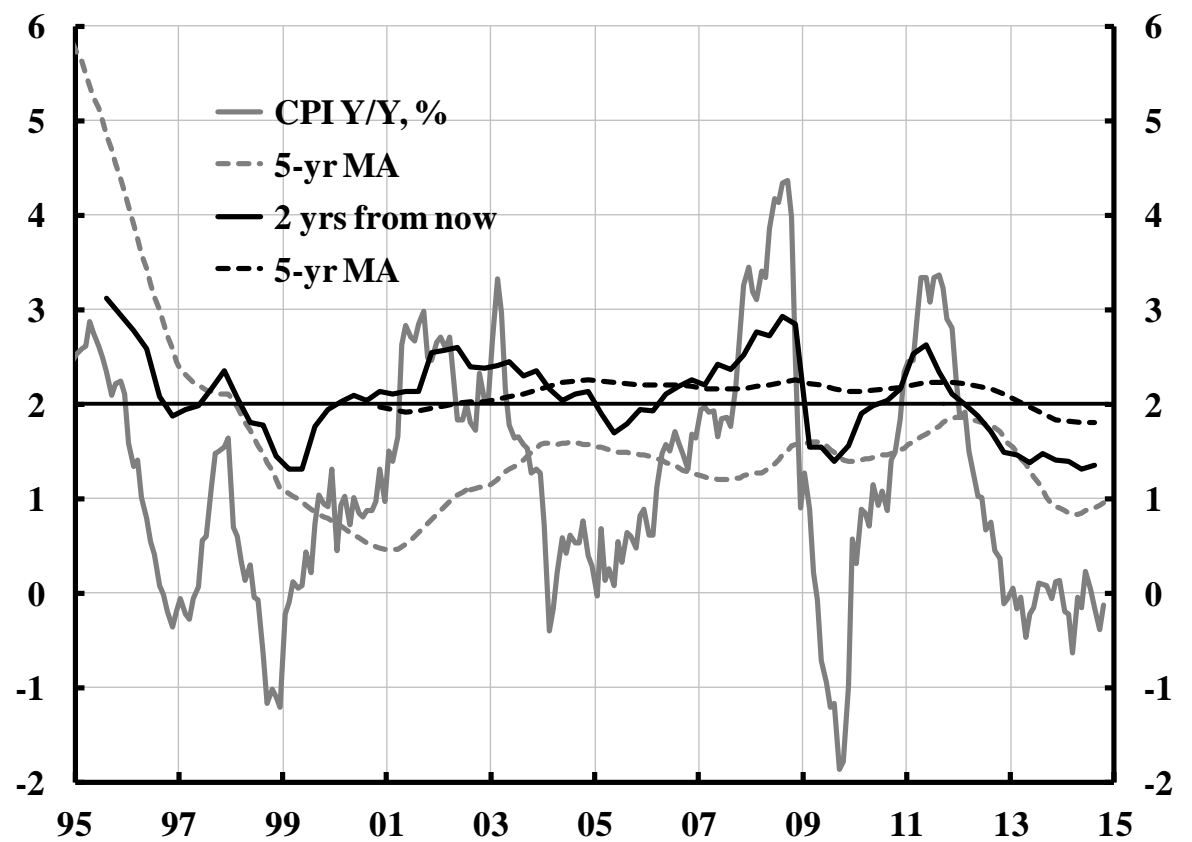

Note: Inflation expectations refer to expectations of annual inflation 2 years from now of all interviewees of the TNS Sifo Prospera survey commissioned by the Riksbank.

Source: Statistics Sweden and TNS Sifo Prospera.

Figure 9. Unemployment in Sweden and New Zealand and counterfactual unemployment in Sweden for a low policy rate

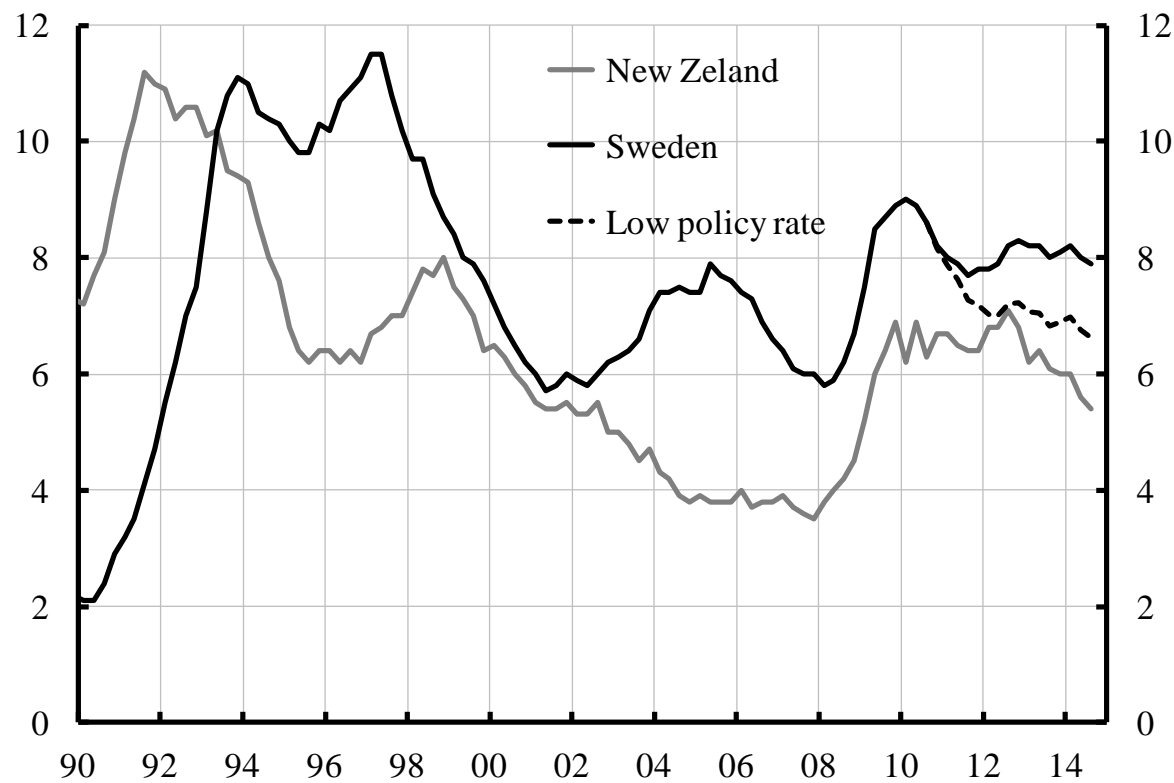

Note: Low policy rate refers to a counterfactual experiment with the Riksbank's main DSGE model,

Ramses, with an assumption of a policy rate at 0.25 percent from June/July 2010.

Source: Datastream and own calculations 
Figure 10. The RBNZ policy rate, the 90-day rate, and the RBNZ 90-day paths, 1999Q1-2014Q3

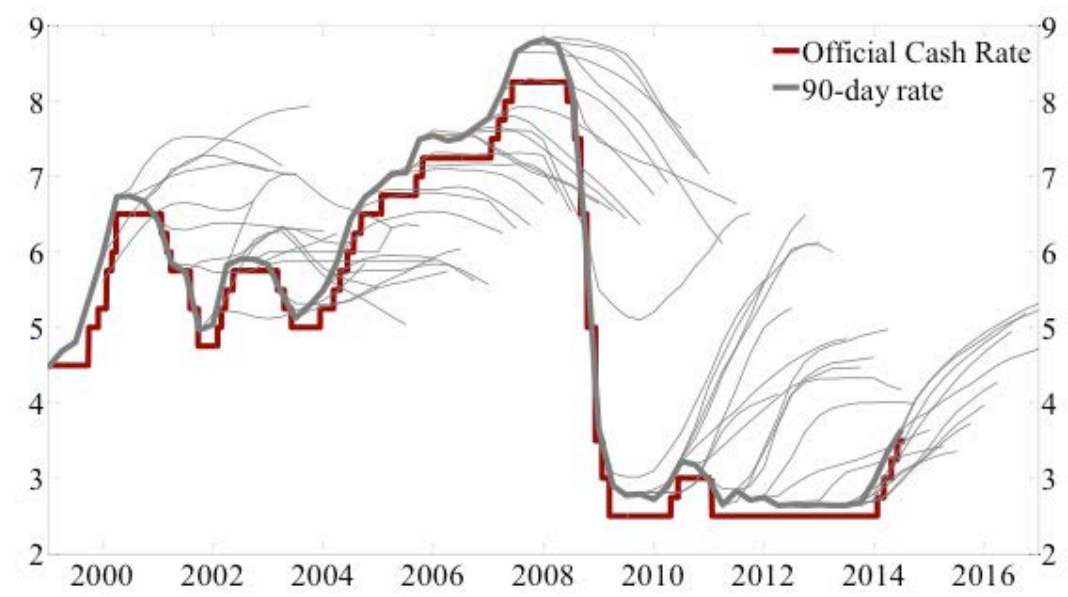

Source: The RBNZ.

Figure 11. The RBNZ policy rate and market policy-rate paths, 2004Q1-2014Q3

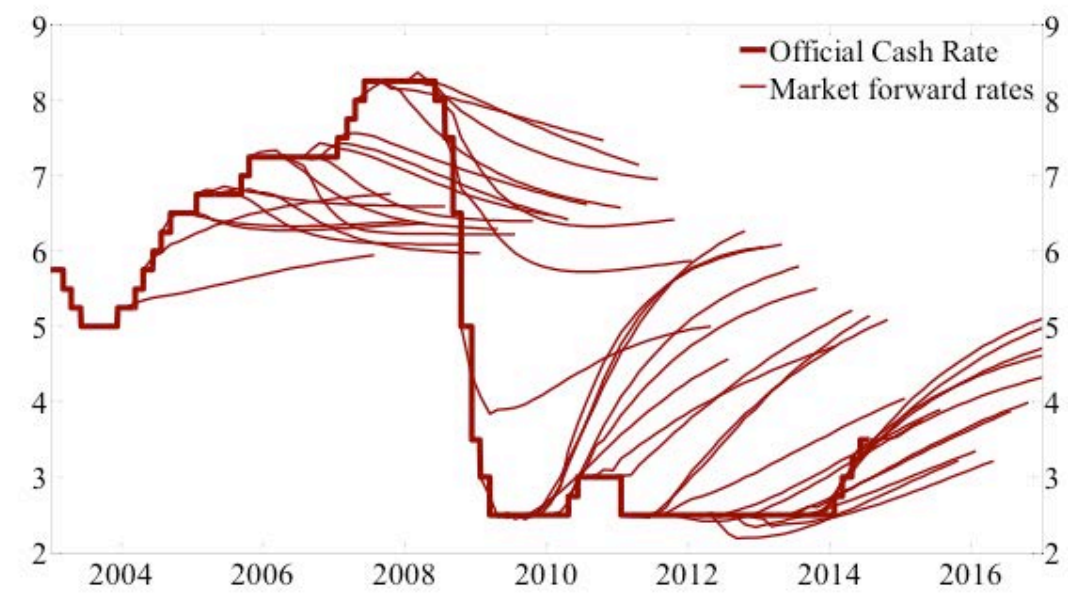

Source: The RBNZ. 
Figure 12. Inflation, 5-year moving average and target midpoint, New Zealand

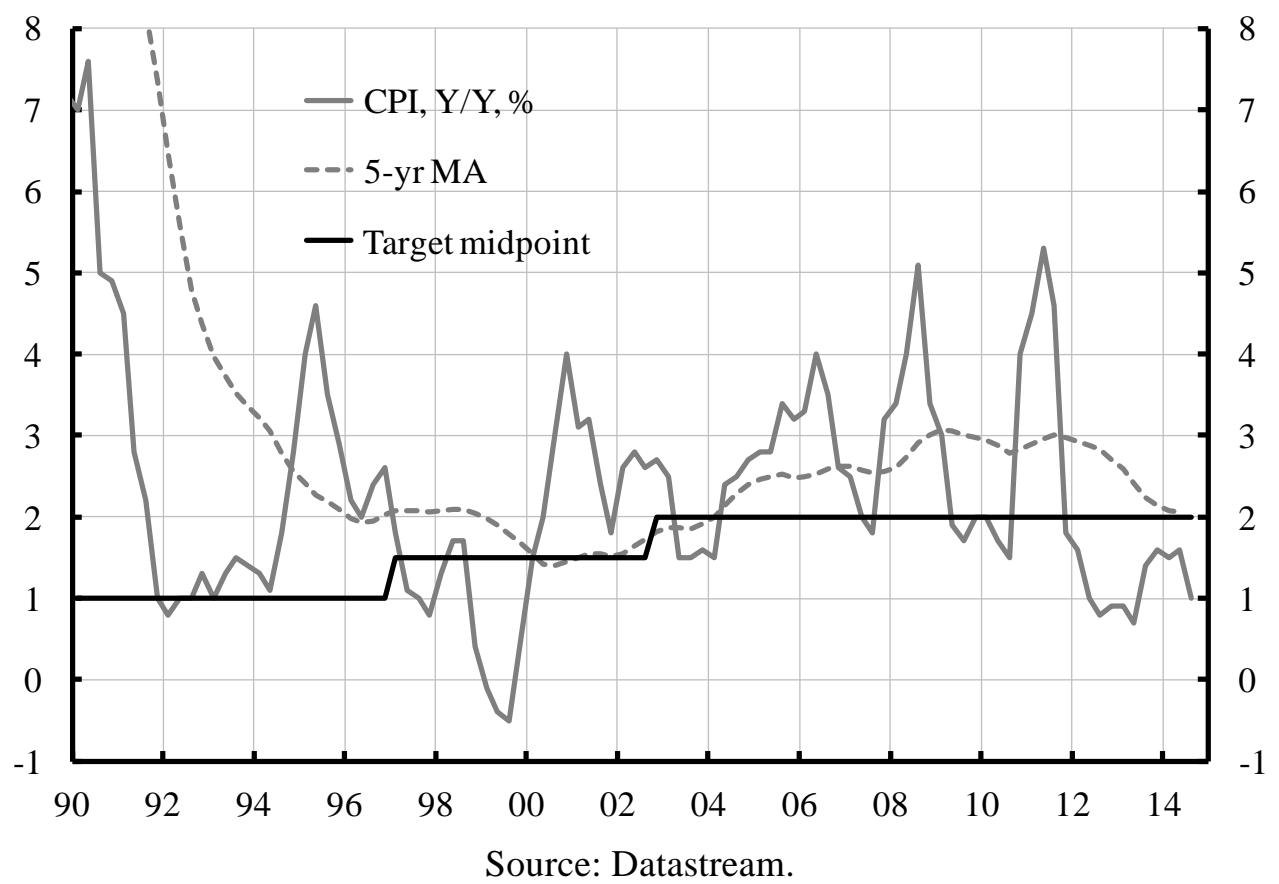

Figure 13. Inflation deviation from target midpoint, 5-year moving averages, and average from 1992, New Zealand

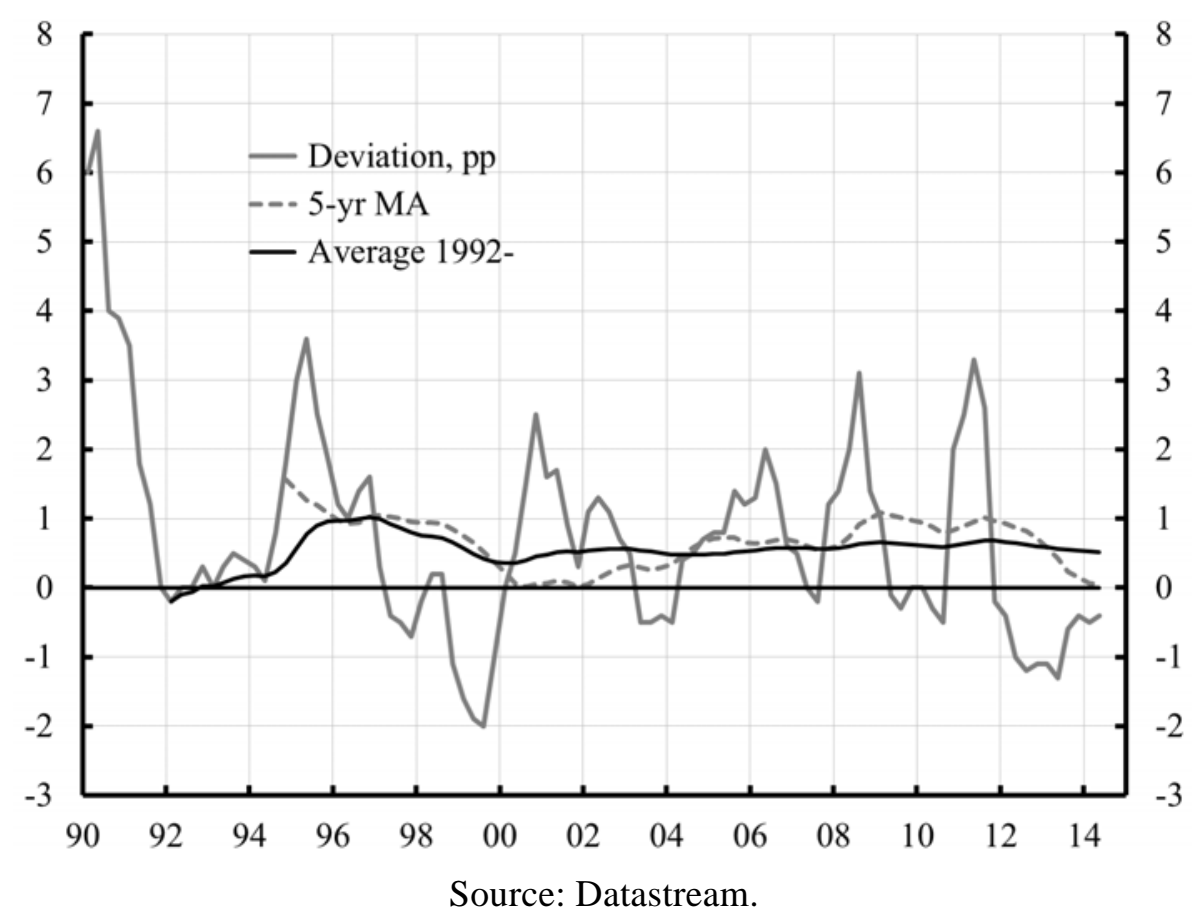


Figure 14. CPI inflation and inflation expectations 2 years from now and 5-year moving averages, New Zealand

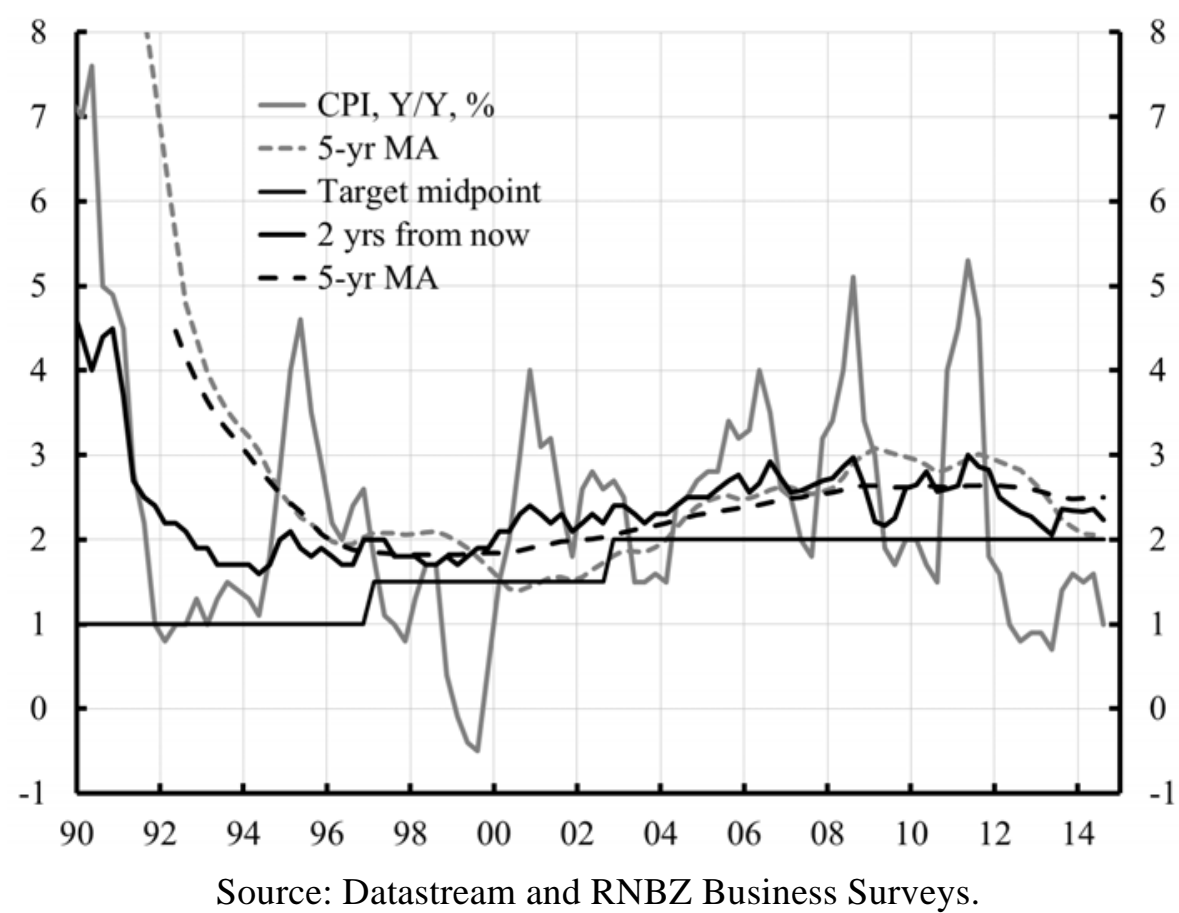

Figure 15. The policy rate, the 90-day rate, the new and old 90-day path and the market policyrate paths before and after the announcement, March 2005

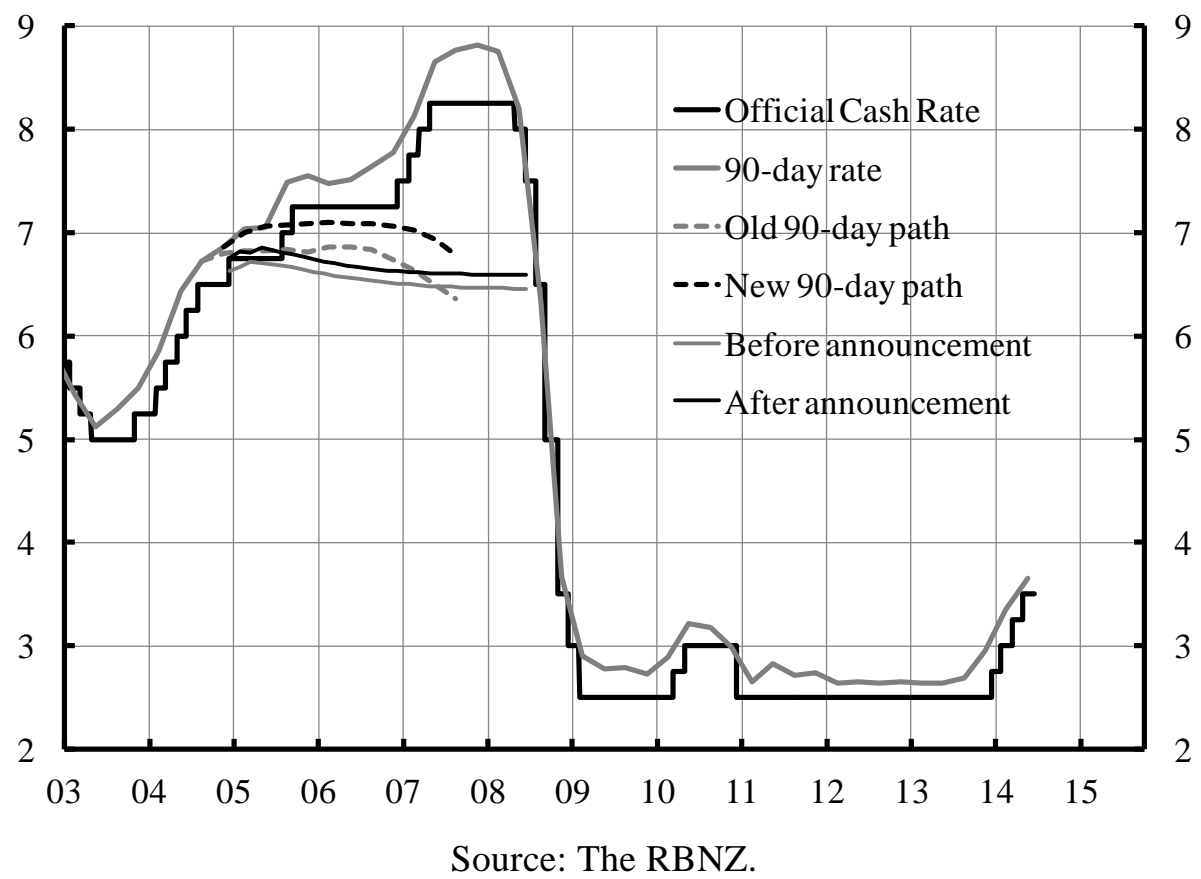


Figure 16. The policy rate, the 90-day rate, the new and old 90-day path, and the market policyrate paths before and after the announcement, March 2009

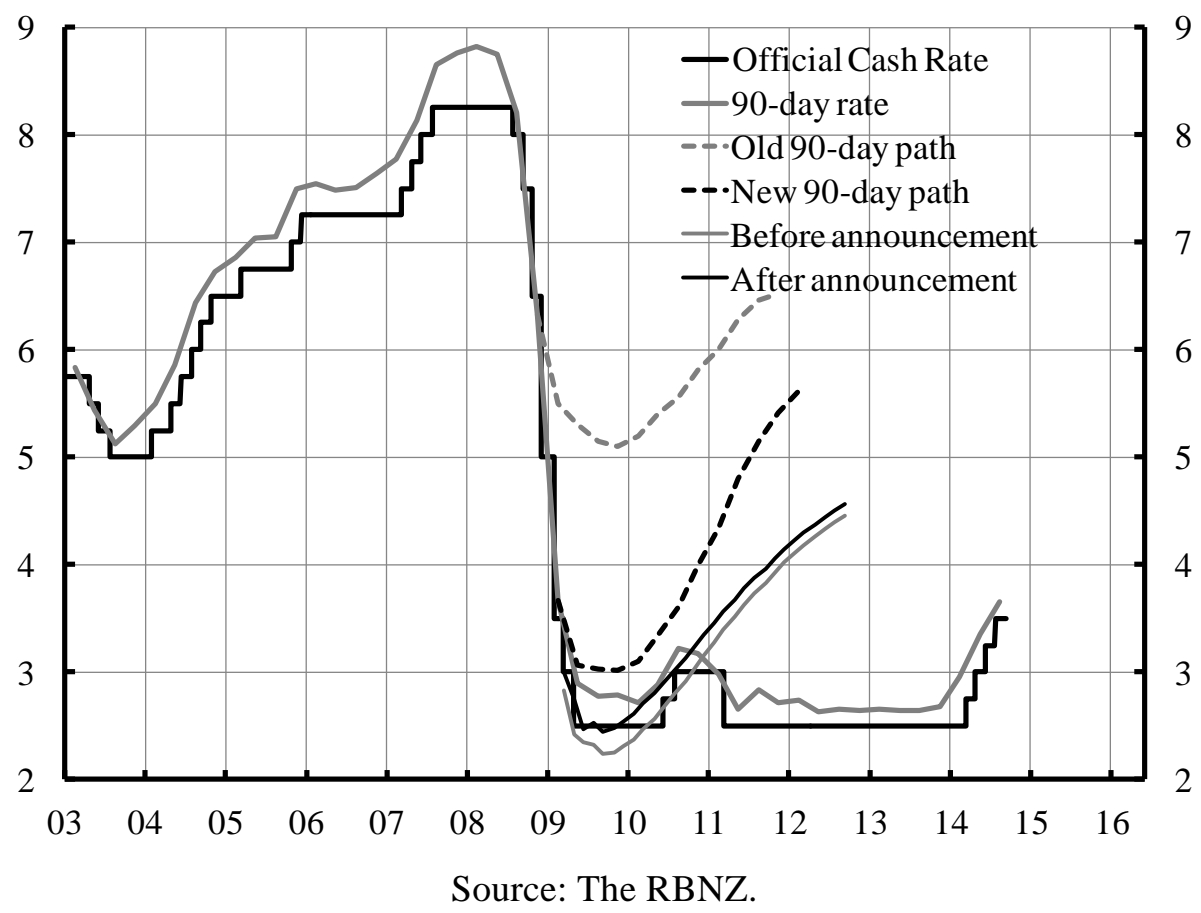

Figure 17. The policy rate, the 90-day rate, the new and old 90-day path, and the market policyrate paths before and after the announcement, December 2009

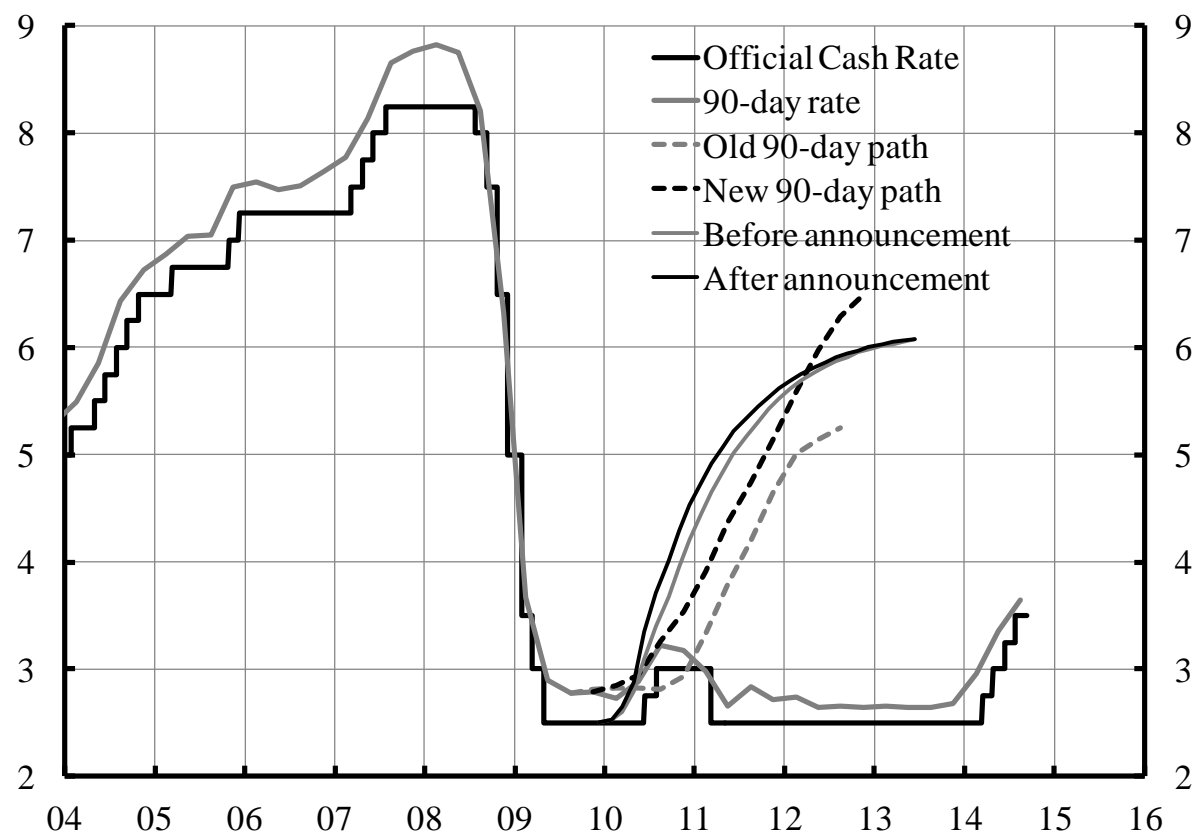

Source: The RBNZ. 
Figure 18. The policy rate, the 90-day rate, the new and old 90-day path, and the market policyrate paths before and after the announcement, December 2011

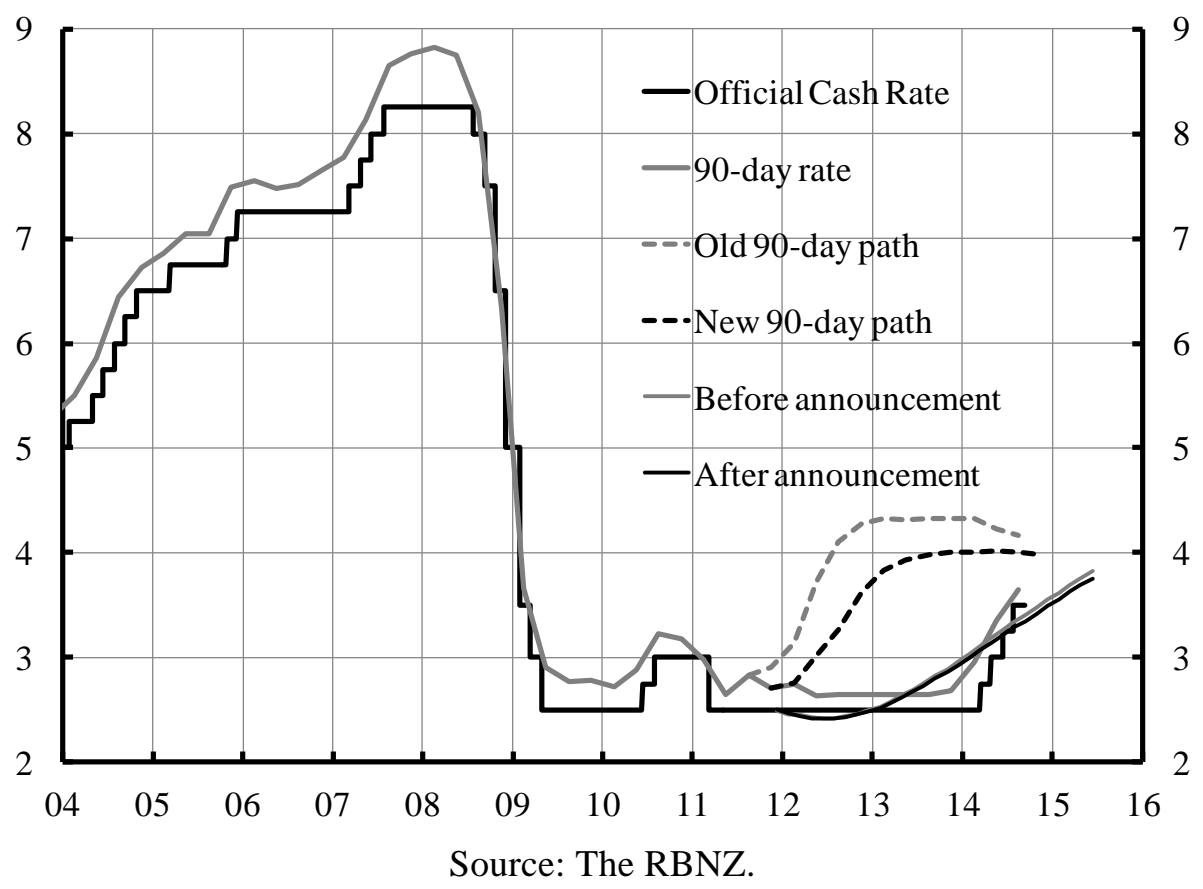

Figure 19. The policy rate, the 90-day rate, the new and old 90-day path, and the market policyrate paths before and after the announcement, March 2012

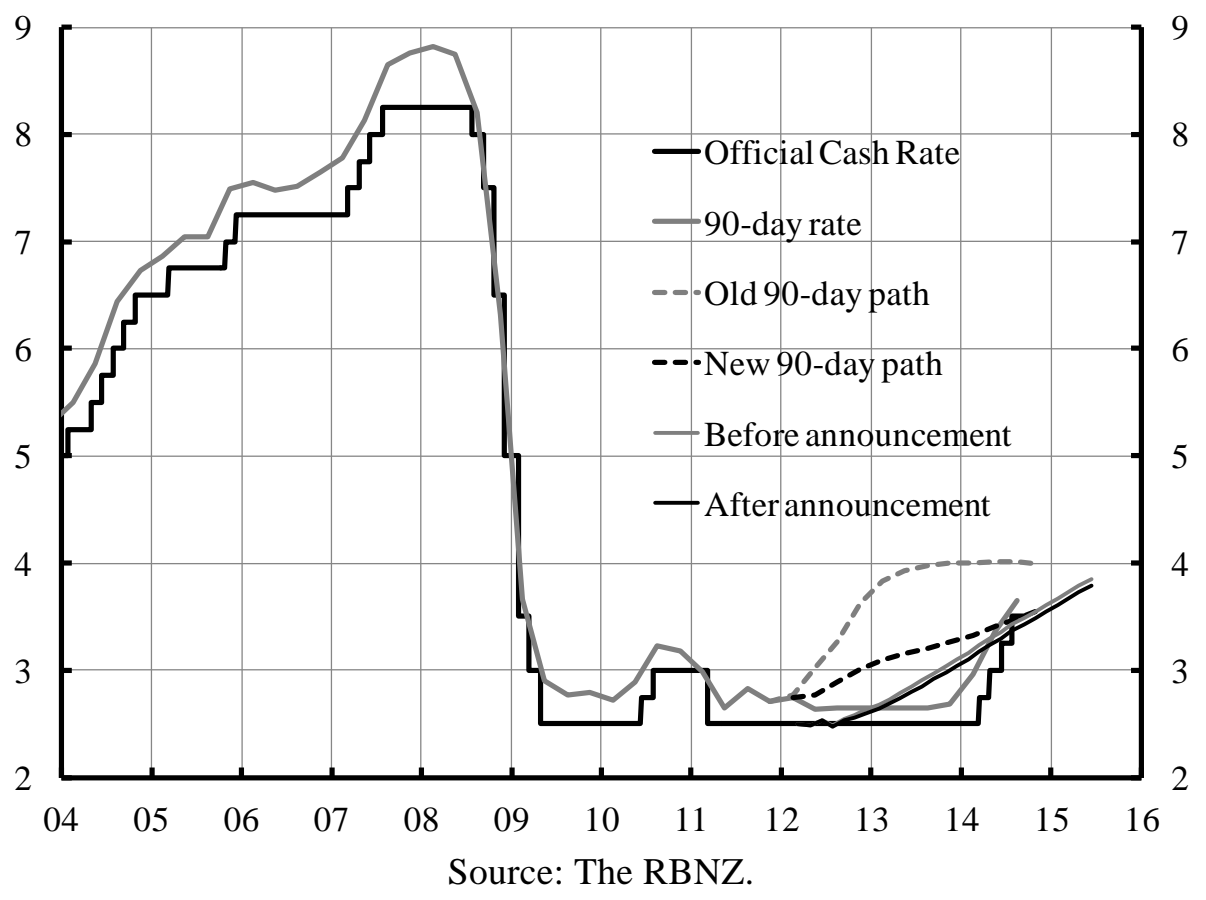


Figure 20. The policy rate, the 90-day rate, the new and old 90-day path, and the market policyrate paths before and after the announcement, December 2013

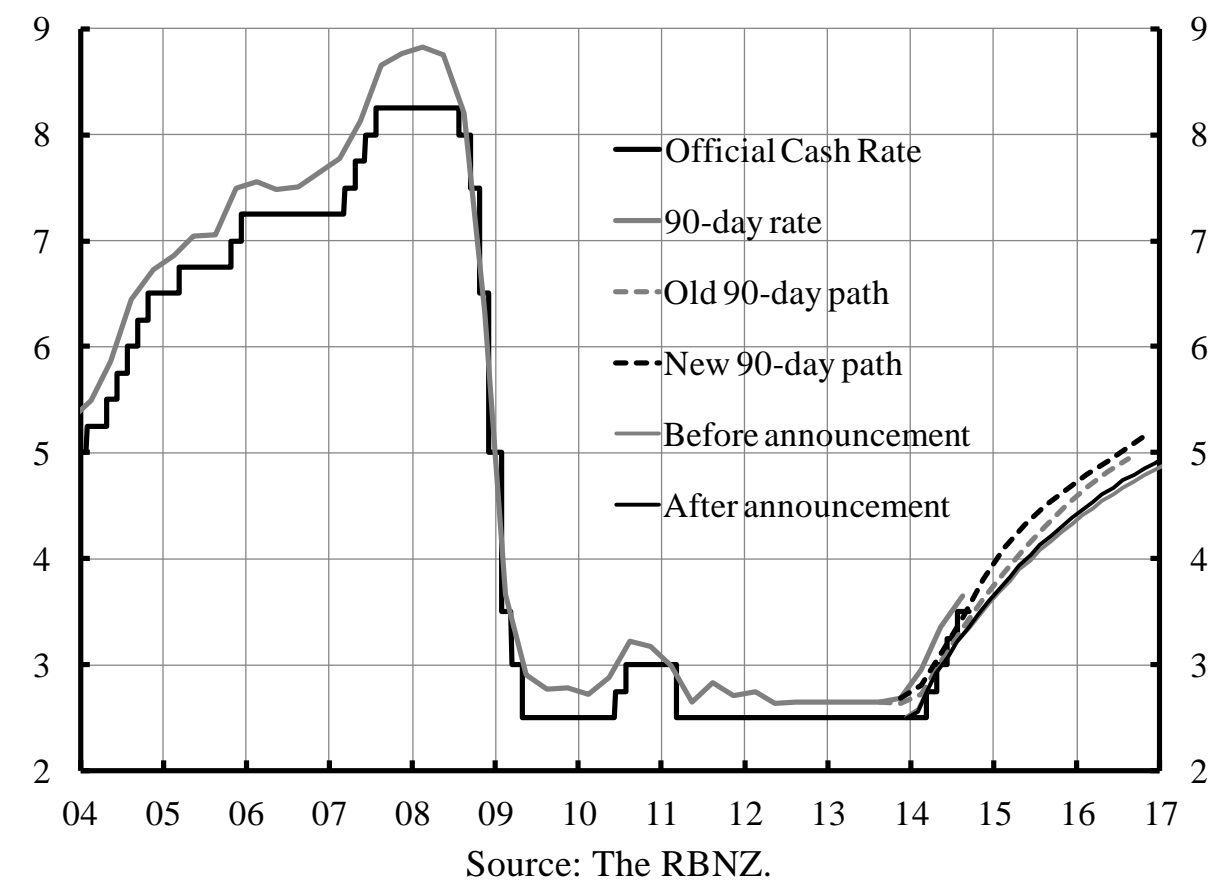

Figure 21. The FOMC participants' assessment of appropriate monetary policy and their median policy-rate path, January 2012

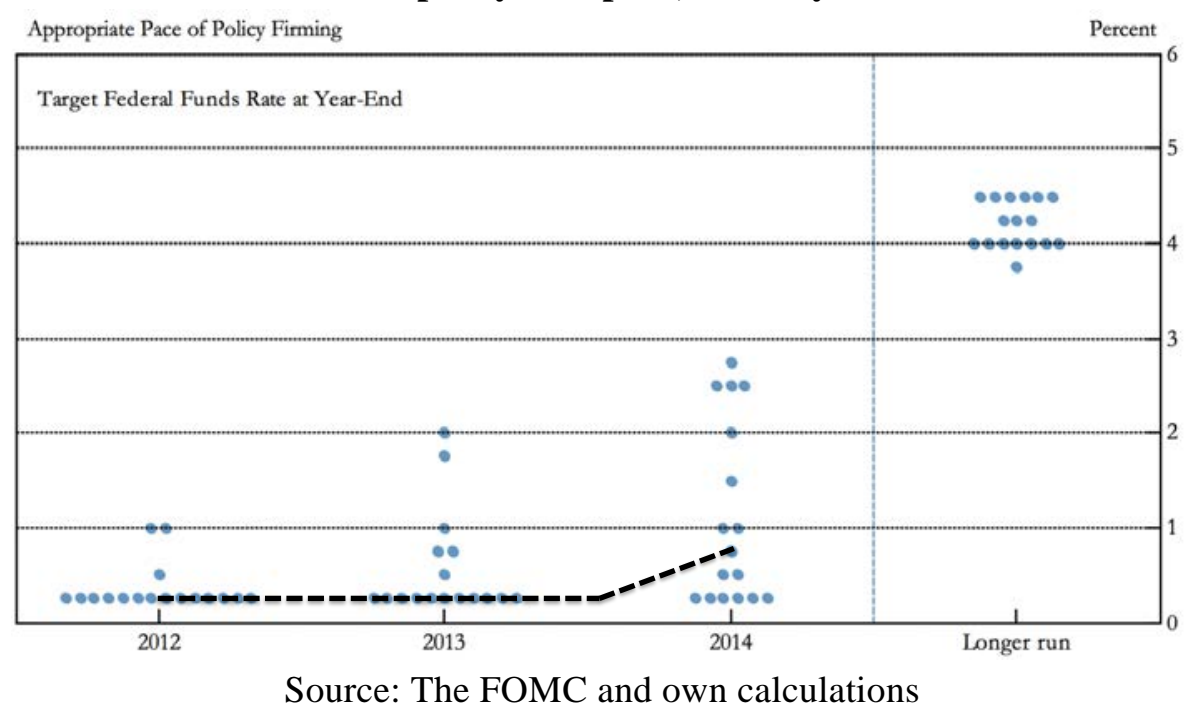


Figure 22. The Federal funds target, the FOMC policy-rate path, and the market policy-rate path before and after the announcement, January 2012

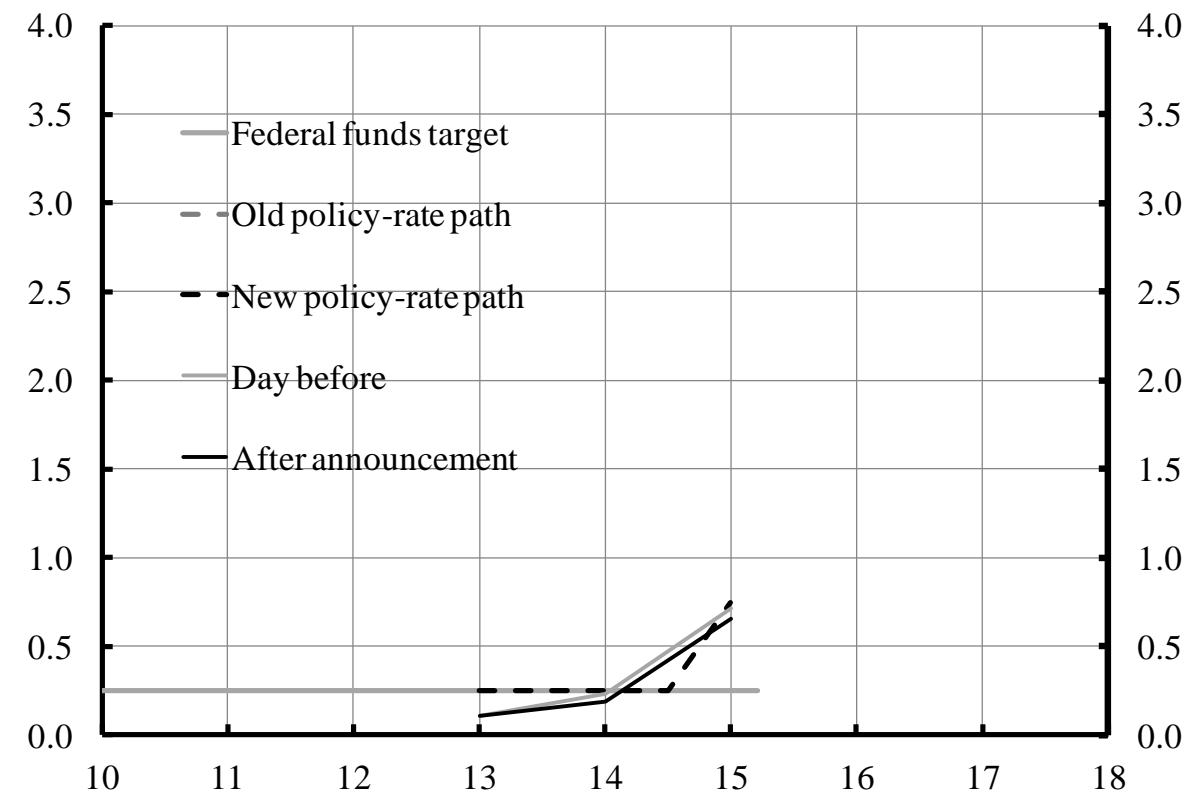

Source: Bloomberg, Haver Analytics and own calculations.

Figure 23. The Federal funds target, the new and old FOMC policy-rate path, and the market policy-rate path before and after the announcement, December 2013

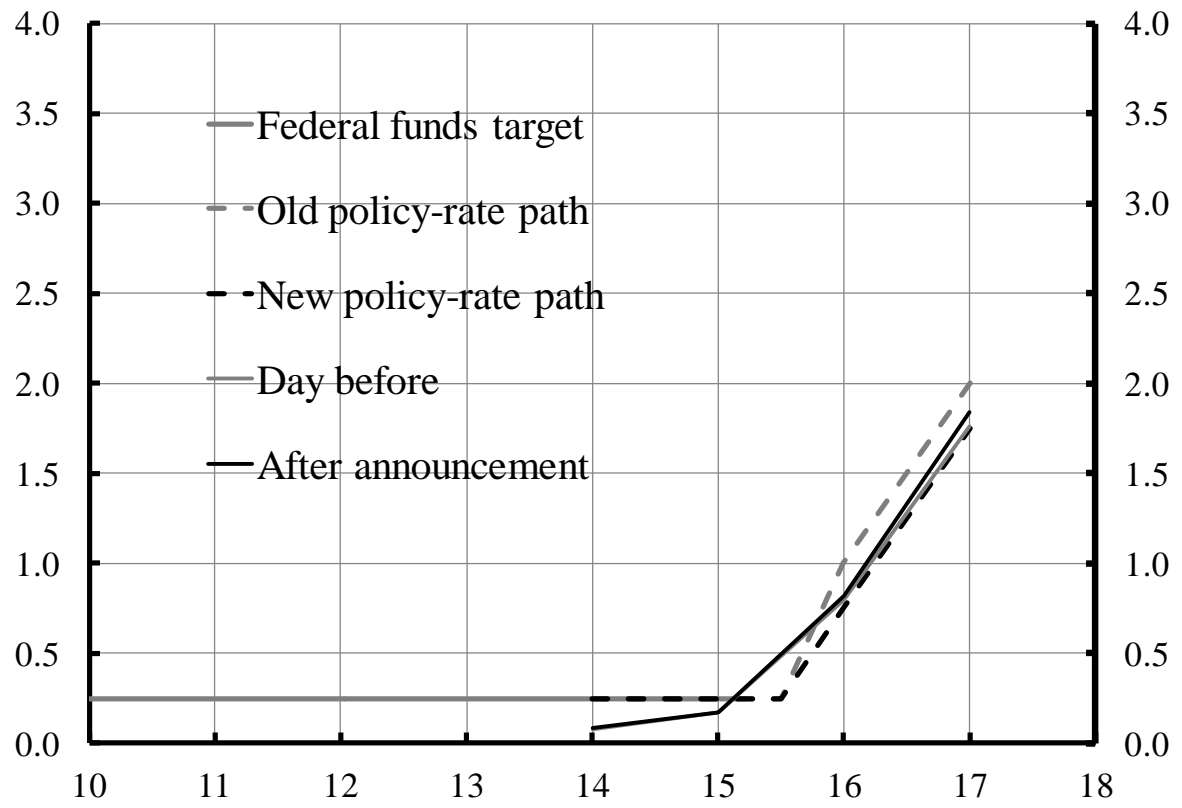

Source: Bloomberg, Haver Analytics and own calculations. 
Figure 24. The Federal funds target, the new and old FOMC policy-rate path, and the market policy-rate path before and after the announcement, December 2014

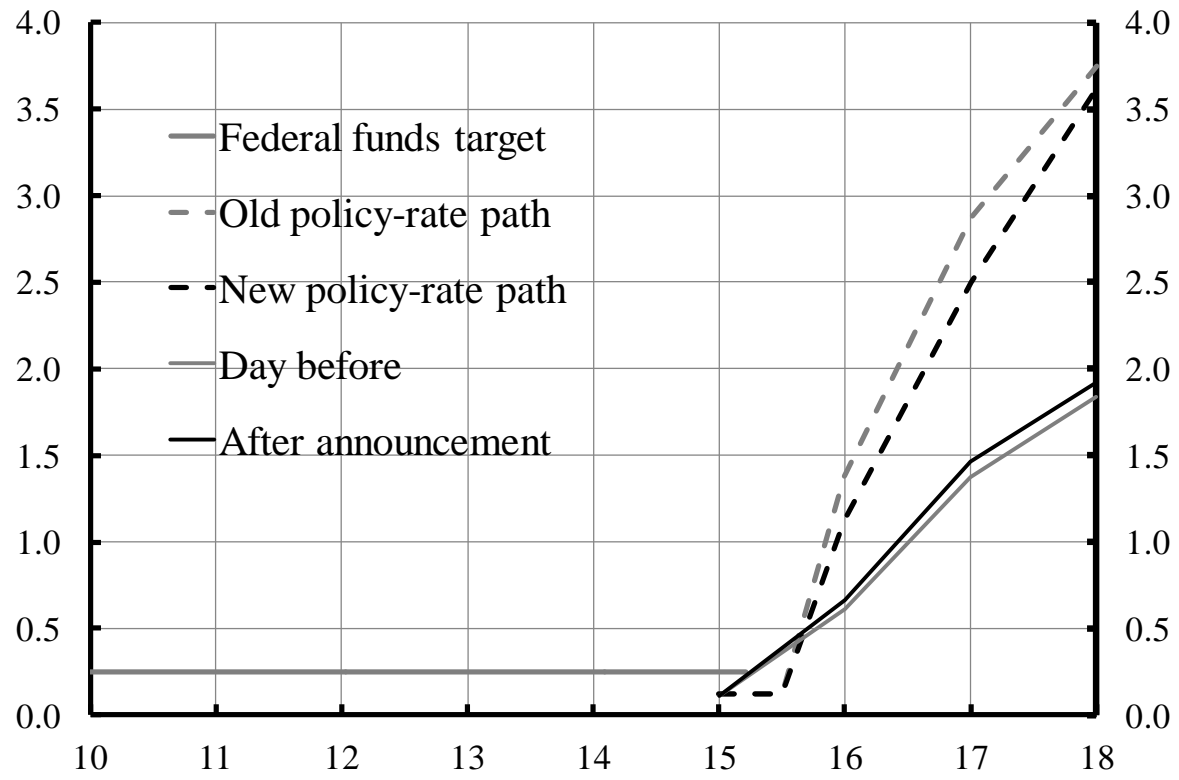

Source: Bloomberg, Haver Analytics and own calculations.

Figure 25. The FOMC participants' assessment of appropriate monetary policy, their median policy-rate path and the market policy-rate path after the announcement, December 2014

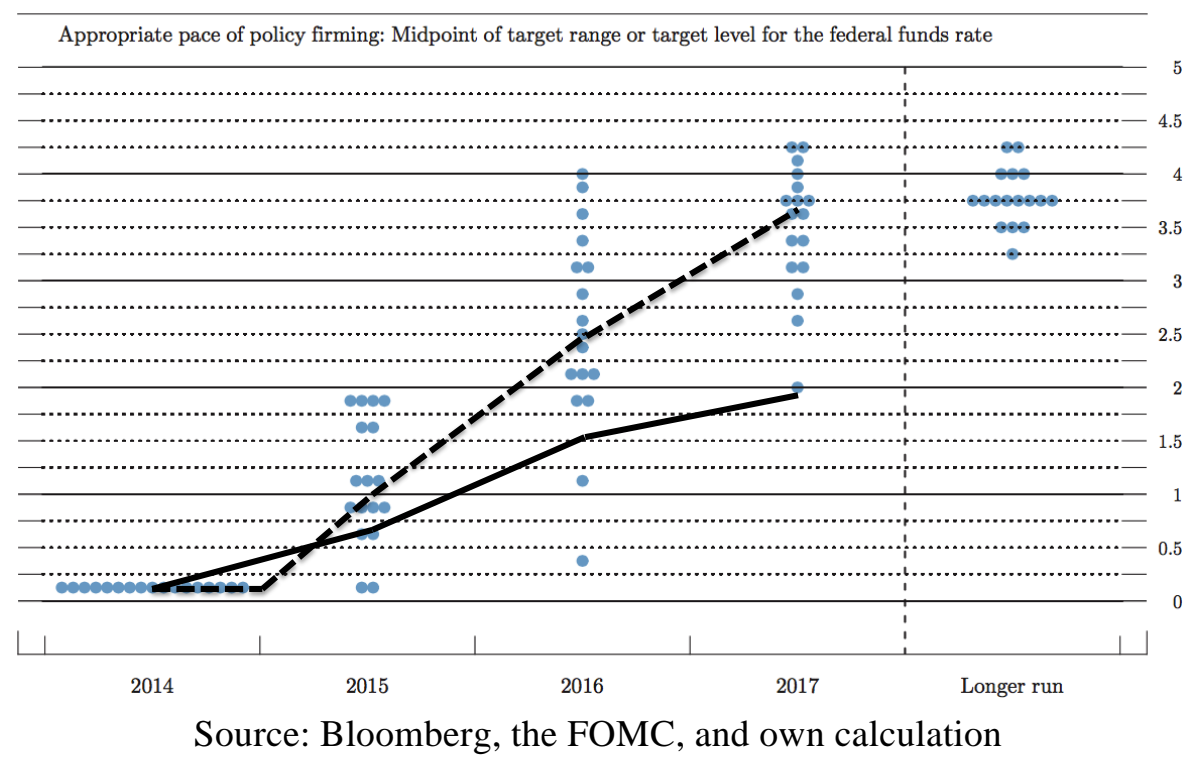


Figure 26. The Federal funds target, the new and old FOMC policy-rate path, and the market policy path before and after the announcement, March 2015

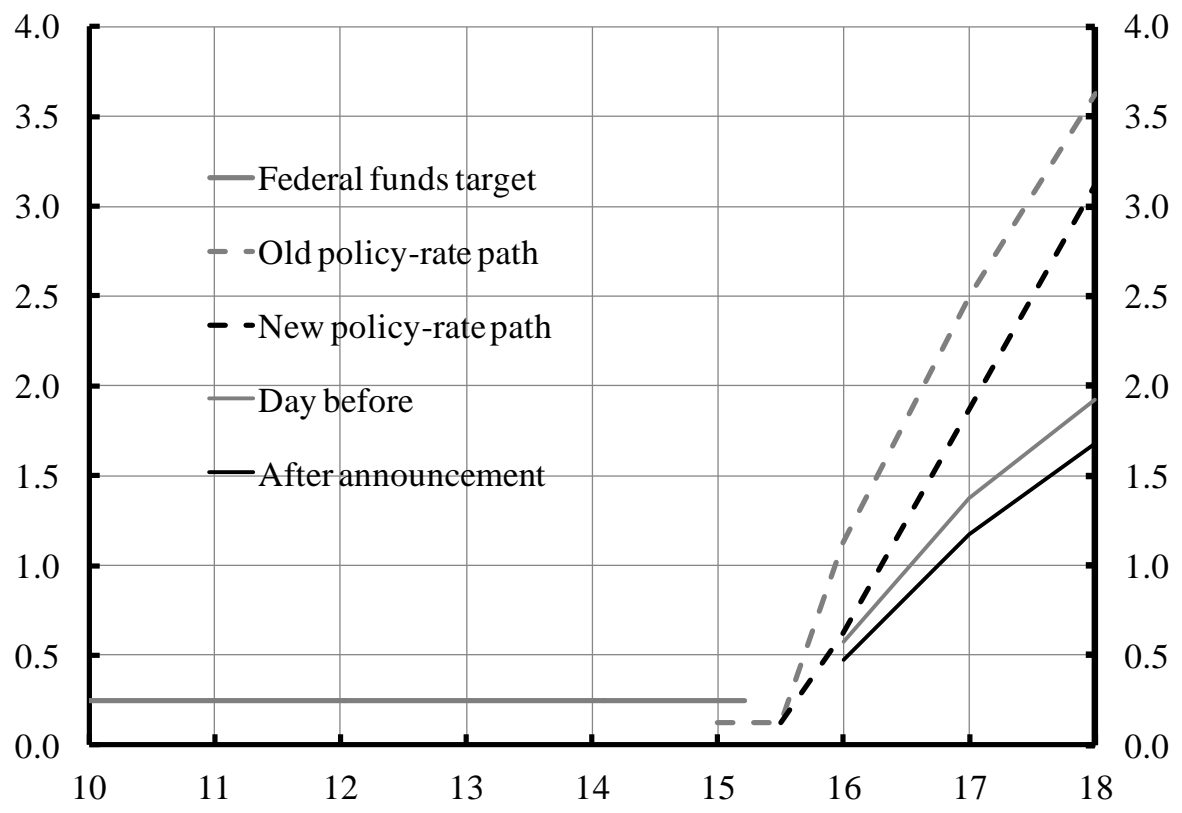

Source: Bloomberg, Haver Analytics and own calculations. 